\title{
TroyAcademy
}

International Journal of Social Sciences

\section{Ada Turizmi Açısından Destinasyon Çekiciliği ve Destinasyon Marka Kimliği Ölçeklerinin Türkçeye Uyarlaması}

Araştırma Makalesi/Research Article

\author{
Gülay KESKİN* Ayşe AKYOL ${ }^{* *}$
}

\section{ÖZET}

$\mathrm{Bu}$ araştırmanın amacı, adalarda turizm kavramını inceleyerek Liu vd. (2017) tarafindan geliştirilen destinasyon çekiciliği ölçeği ile Tsaur vd. (2016) tarafından geliştirilen destinasyon marka kimliği ölçeğinin Türkçeye uyarlanmasıdır. Araştırmada ölçeklerin yapı geçerliği ve güvenirliği incelenmiştir. Açıklayıcı faktör analizi (AFA) ile ölçeklerin yapı geçerlikleri incelenmiştir. Açıklayıcı faktör analizi (AFA) sonucunda destinasyon çekiciliği ölçeği için toplam varyansın \%62,968'ini açıklayan 3 faktörlü bir yapı elde edilmiştir. Destinasyon marka kimliği ölçeği için toplam varyansın \%62,038'ini açıklayan 6 faktörlü bir yapı elde edilmiştir. Ardından doğrulayıcı faktör analizi (DFA) çalışması yapılarak, ölçeklerin model uyum indeksleri ve güvenirliği hesaplanmıştır. Doğrulayıcı faktör analizi (DFA) sonuçlarına göre destinasyon çekiciliği ölçeğinin model uyum indekslerinin (X2=279,615; X2/df =1,877; RMSEA=0,074; $\mathrm{GFI}=0,854 ; \mathrm{CFI}=0,929 ; \mathrm{SRMR}=0,0609$ ) geçerli düzeyde olduğu bulunmuştur. Destinasyon marka kimliği ölçeği DFA analizinde model uyum indekslerinin $(\mathrm{X} 2=547,486 ; \mathrm{X} 2 / \mathrm{df}=1,935 ; \mathrm{RMSEA}=0,077 ; \mathrm{GFI}=0,856 ; \mathrm{CFI}=0,912 ; \mathrm{SRMR}=0,0588)$ kabul edilebilir uyum sınırları dahilinde yer aldığı bulunmuştur. Güvenirlik analizleri sonucunda destinasyon çekiciliği ölçeğinin hesaplanan $(\alpha)$ değerinin 0,872 ; destinasyon marka kimliği ölçeğinin $(\alpha)$ değerinin 0,810 olduğu ve ölçeklerin güvenilir olduğu bulunmuştur. Elde edilen bulgular sonucunda iki ölçeğinde uyum indekslerinin kabul edilebilir düzeyde olduğu ve tüm faktörlerin birbiriyle olumlu ve anlamlı düzeyde ilişkili olduğu belirlenmiştir.

\section{Anahtar Kelimeler: Ada Turizmi, Destinasyon Çekiciliği, Destinasyon Marka Kimliği, Ölçek Uyarlama}

\section{Adaptation of Destination Fascination and Destination Brand Identity Scales to Turkish in Terms of Island Tourism}

\begin{abstract}
The purpose of this study is to examine the concept of tourism in the islands and adapt the Destination Fascination Scale developed by Liu et al. (2017) and the Destination Brand Identity Scale developed by Tsaur et al. (2016) into Turkish. The construct validity and reliability of the research scales were examined. The construct validity of the scales was examined by Explanatory Factor Analysis (EFA). As a result of the explanatory factor analysis (EFA), for destination fascination scale a 3-factor structure that explains 62,968\% of the total variance was obtained. For the destination brand identity Scale, a 6-factor structure that explains

* Öğr. Gör., Çanakkale Onsekiz Mart Üniversitesi, Gökçeada Meslek Yüksekokulu, gulaykeskin@comu.edu.tr, ORCID-ID: 0000-0003-2706-8868

** Prof. Dr., İstanbul Arel Üniversitesi, İktisadi ve İdari Bilimler Fakültesi, ayseakyol@arel.edu.tr, ORCID-ID: 0000-0002-4039-5823
\end{abstract}


$62,038 \%$ of the total variance was obtained. Subsequently, by conducting a confirmatory factor analysis (CFA) study, the model fit indexes and reliability of the scales were calculated. According to the confirmatory factor analysis (CFA) results, it was found that the model fit indexes of the destination fascination scale $(\mathrm{X} 2=279,615$; $\mathrm{X} 2 / \mathrm{df}=1,877$; RMSEA=0,074; GFI=0,854; $\mathrm{CFI}=0,929 ; \mathrm{SRMR}=0,0609)$ were at a valid level. In the destination brand identity scale CFA analysis, it was found that the model fit indexes (X2=547,486, X2/df $=1,935$; RMSEA=0,077; GFI=0,856; CFI=0,912; SRMR=0,0588) were within the acceptable fit limits. As a result of the reliability analysis, it was found that the calculated $(\alpha)$ value of the destination fascination scale was 0,872 the $(\alpha)$ value of the destination brand identity scale was 0,810 and the scales were reliable. As a result of the findings, it was determined that the fit indexes on the two scales were at an acceptable level and all factors were positively and significantly related to each other.

Keywords: Island Tourism, Destination Fascination, Destination Brand Identity, Scale Adaptation

\section{GíRiş}

Turizm destinasyonu markalaması, bir ülke veya bölge tarafından turist ziyaretlerini çekmek için gerçekleştirilen bir pazarlama stratejisidir. Destinasyonlar sahip oldukları tarihleri, doğal potansiyelleri ve kültürel miraslarını turistik cazibe ve potansiyel çekici unsurlar olarak kullanmaktadır (Hasyim vd., 2020: 1). Son derece rekabetçi bir ortamda daha fazla turist çekmek için destinasyonlar güçlü destinasyon markaları oluşturmaya ve onları tüketicilerin zihninde doğru bir şekilde konumlandırarak destinasyon marka kimliği yaratmaya çalışmaktadır (Frere vd., 2021: 193). Gittiği destinasyonlardan memnun ayrılan turistler, o destinasyonları tekrar ziyaret ederek çevrelerine bu destinasyonlarla ilgili tavsiyeler vermekte destinasyonların bilinirliğinin artmasına ve destinasyonların marka kimliğinin gelişmesine katkı sağlamaktadır. Destinasyonlar, yarattıkları ve sundukları çekiciliklerle kendi başına bir talep oluşturan ve temel ziyaret amacı sırasında ortaya çıkan ihtiyaçların karşılanması için planlamayı gerektiren bir yer parçası şeklinde tanımlamaktadır (Aksu, 2015: 4). Destinasyonlar gezip, görülebilen, içinde turistleri çeken farklı unsurların bulunduğu çeşitli cazibe merkezleridir. Adalar doğaları, bitki örtüleri, temiz denizleri, biyoçeşitlilikleri, kültürel, tarihi zenginlikleri, farklı etnik gurupların bir arada kurmuş oldukları dostane ilişkiler ile eşsiz çekici unsurları içinde bulunduran destinasyon merkezleridir.

Bu araştırmanın amacı, Liu vd. (2017) tarafından geliştirilen destinasyon çekiciliği ölçeği ve Tsaur vd. (2016) tarafından geliştirilen destinasyon marka kimliği ölçeğini Türkçeye uyarlamak ada turizmi kavramını ele alarak ada turizmi ve turizmde destinasyon pazarlaması üzerine yapılan çalışmalara katkı sağlamaktır. Liu vd. (2017) tarafından geliştirilen destinasyon çekiciliği ölçeği daha önce Karadamar vd. (2018) araştırmalarında “destinasyon hayranlığı” olarak Türkçeye uyarlamışlardır. Bu araştırmada "destinasyon çekiciliği” adı altında tekrar ele alınarak geçerlik ve güvenirliği incelenecektir. Tsaur vd. (2016) tarafından geliştirilen Türkçe alan yazında destinasyon marka kimliğini ölçen ilk Türkçe ölçek olarak alan yazına kazandırılması amaçlanmaktadır. 
Araştırma Gökçeada'ya gelen turistler üzerinde iki farklı örneklemden (n1:220, n2:160) toplanarak yürütülmüştür. Öncelikle ölçeklerin dil geçerliği sağlanmıştır. Dil geçerliği sağlandıktan sonra ölçeklerin yapı geçerliği ve güvenirlikleri incelenmiştir. İlk örneklem üzerinde açıklayıcı faktör analizi (AFA) uygulanarak ölçeklerin yapı geçerlikleri incelenmiştir. Aynı dönemde Gökçeada’ya gelen ve veri toplanan ikinci örneklem grubundan elde edilen veri setine doğrulayıcı faktör analizi (DFA) çalışması yapılmıştır. Ölçeklerin model uyum indeksleri incelenerek güvenirlikleri hesaplanmıştır.

\section{ADA TURIZMI}

Ada turizmi yeni bir turizm türü değildir. Adalar binlerce yıldır dinlenme ve rahatlama yeri olarak kullanılmaktadır. Romalılar, Capri Adası'nı iki bin yıl önce bir tatil beldesi olarak kullanmışlardır. Akdeniz, Atlantik ve Pasifik’teki adalar insanların rahatlamak ve gençleşmek için gittikleri yerler olarak bilinmektedir (Stylidis ve Terzidou, 2007: 955).

Adalarda turizm, belirli coğrafi mekânlarda yer alan doğal kaynaklarla ziyaretçilerin ihtiyaçlarını karşılayan önemli bir ticari uğraştır. Özellikle, "ada turizmi" terimi, bir adada aile pansiyonları, kurumsal oteller ve diğer ilgili ticari alanların kurulmasının yanı sıra adanın doğal noktaları ve gelişimlerinin entegrasyonunu ilerleterek turizmin gelişmesi sağlamaktadır. Bu da adanın yerel nüfus artışını, çevresel iyileştirmeyi, tesislerin artmasını ve işlevsel iyileştirmeyi etkilemektedir (Yang vd., 2016: 261). Ayrıca adalarda gerçekleştirilen turizm faaliyetleri, bu destinasyonların ticari gelişimini, ekonomik büyümesini sağlamakta, aynı zamanda ev sahiplerinin refahını artırmaktadır.

Ada ekosistemleri, çeşitli ekosistemlerin çoğu tarafından paylaşılan çok spesifik fiziksel, ekonomik ve sosyo-kültürel özelliklere sahiptir. $\mathrm{Bu}$ özellikler, daha fazla izolasyona, ekonomik olarak yararlanılabilir kaynakların yokluğuna, tüketim için büyük dış bağımlılığa, yüksek benzersizlik düzeyine sahip kültürel ve doğal mirasa ve yüksek yoğunlukta endemik bitki ve hayvan türlerine yol açan iyi tanımlanmış coğrafi sınırları içermektedir (Rio-Rama, 2020: 1).

Adalar, günlük yaşamdan farklı yaşam tarzları sağlayabildiğinden turistler arasında cazip yerler olarak kabul edilmektedir. Bir ada destinasyonunun romantizm, kaçış ve egzotizm duyguları yaratması, değişik deneyimler sunması, kültürel yapısından fiziki konumundan kaynaklanan benzersizliği adalara gelmek için geçerli neden olarak görülmekte ve turistleri etkilemekte önemli rol oynamaktadır (Moon ve Han, 2018: 71). Adaların sahip oldukları özellikler; (turistler tarafından uzak bir cennet olarak algılanmaları, turistlerde romantizm duygusu uyandırması, rahatlatıcı psikolojik etkileri), doğal güzellikleri, çevresel cazibe kaynakları ve yerel bağlamda eşsiz doğaları ile bu destinasyonlarda turizmi artırmaktadır. 


\section{DESTINASYON ÇEKICILİĞİ}

Destinasyon kavramı literatürde çekim yeri, turizm bölgesi ve turistik yer şeklinde ifade edilebilmektedir. Destinasyon, turistik ürünlerle birlikte turistlere deneyimler sunan ülke, ada veya şehir gibi iyi tanımlanmış coğrafik alanlardan oluşmaktadır (Davras ve Uslu, 2019: 681). Ayrıca, Gönenç (2010:7) destinasyonu; yörenin dışından gelen yabancıların, kalacakları süre içerisinde alacakları turistik mal ve hizmetlerin sunulduğu, doğal güzellikleri ve çekicilikleri olan bir alan, çeşitli turistik mal ve hizmetlerin ve o yöreden elde edilen, kazanılan ve tatil sonrasında hafizada kalan deneyimlerin, bir potada eritilmiş bir birleşimi olarak ifade etmektedir. Destinasyon çekiciliği; bir destinasyonun, turistlerin ilgi alanlarına göre destinasyondaki ayrıntıları keşfetmeleri ve destinasyonun sahip olduğu özellikleri özgürce ve kişisel olarak deneyimlemeleri olarak tanımlanır (V.G. vd., 2021: 2). Bir destinasyon, turistlerin ihtiyaçlarını ne kadar karşılayabiliyorsa, o kadar çekici olarak algılanmakta ve belirli bir destinasyonun seçilme olasılı̆̆ı o kadar artmaktadır (Song vd., 2020: 511). Çekicilik, turizm etkinliğinin oluşmasında aktif rol oynayan faktörlerden birisidir. Demir (2010), Dalyan'a özgü çekici faktörlerin turistlerin tatil yeri seçimindeki etkisini belirlemeye yönelik araştırmasında, çekici unsurları; tarihi ve doğal çekicilikler, rekreasyonel çekicilikler, konaklama ve ulaşım olanakları ve sosyo-kültürel değerlere ilişkin destinasyon çekicilik unsurları olarak tanımlamıştır. Vengesayi vd. (2009) tarafından gerçekleştirilen araştırmanın sonuçlarına göre, destinasyonların sahip olduğu kültür, doğa, tarih, mimari yapılar, yemek kültürü, geleneksel sanatlar gibi unsurlar destinasyon çekicilik unsurlarının belirleyicileridir.

Liu vd. (2017) geliştirdikleri ölçekte destinasyon çekicilik unsurlarını çok boyutlu bir kavram olarak ele alarak; gizem (mystique), zenginlik (richness), cazibe (attractiveness), benzersizlik (uniqueness), uygunluk (fitness) ve sicakkanlılık (friendliness) olarak açıklamaktadır. Destinasyon çekiciliği unsurları aşağıda incelenmektedir:

\subsection{Gizem}

Gizem; destinasyonların sahip olduğu hikayelerin, turistlerin araştırma ve keşfetme motivasyonlarını ne ölçüde artırdı̆̆ 1 olarak tanımlanabilir. Gizemli destinasyonlar turistlerin deneyimlerine ve destinasyonlara hayranlık duymalarına katkıda bulunur (Liu vd., 2017: 257).

Mitolojik öyküler ve efsaneler, masalsı anlatımlarıyla, olağanüstü yeteneklere ve özelliklere sahip kahramanlarıyla, ilgi çekici ve insanı sürükleyen olay örgüleriyle insanları cezbedebilmektedir. Dolayısıyla mitolojik öyküler ve efsanelerde ismi geçen yerler de bu ilgiden etkilenmektedir. Anadolu coğrafyası da başta Yunan mitolojik öykü ve hikâyeleri olmak üzere pek çok mitolojik öyküler ve efsanelerin doğuş yeri olarak dikkat çekmektedir (Sezer, 2020: 2463). Ayrıca Türkiye'deki Ege adalarının çoğunda Yunan mitolojisi hakimdir. Diğer adaların birçoğunda da efsaneler, masallar 
geçmişten günümüze kadar anlatılmakta, gizemli, büyüleyici yönleriyle turistlerde merak uyandırmaktadır.

\subsection{Zenginlik}

Turizm destinasyonlarındaki temel kaynak ve çekiciliklerin en önemlisi; insanların herhangi bir katkısı ve emeği olmadan meydana gelmiş olan doğal ya da fiziksel zenginliklerdir. Bu zenginlikler destinasyonun iklim yapısı, doğal güzellikleri, görünümü, manzarası, flora ve faunası, bozulmamış doğası ile ulusal parklar ve alanlardan oluşmaktadır. Bununla birlikte, tarihi eserler, dinsel yapılar ve anıtlar, sanatsal ve mimari özellikler, geleneksel sanatlar ve bölgenin yerel kültürü gibi faktörler de temel kaynak ve çekicilikler kapsamındadır (Eren vd., 2017: 482).

Doğal, tarihi ve kültürel kaynakların zenginliği, iklim ve coğrafi koşulların farklı turizm ürünleri açısından elverişliliği, misafirperverlik, güçlü bir turizm endüstrisi, Türk turizminin güçlü yönleridir. Yedi coğrafi bölgemizin her biri kültürleri ve kültürel çekicilikleri ile ayrı bir öneme sahiptir (Emekli, 2005:103). Geçmiş medeniyetlerin kalıntıları ve o dönemde yaşayan insanların, makinelerin olmadığg zamanlarda ulaştıkları teknolojik düzey turistleri etkileyebilmektedir. Gelenek ve görenekler, kültürel varlıklar gibi faktörler de sosyo-kültürel unsurlar olarak seyahat edilecek yeri çekici k1lan önemli unsurlardır (Aktaş ve Batman, 2010: 378).

\subsection{Cazibe}

Kentlerin ekonomik, kültürel ve sosyal açıdan gelişimi, turizm açısından bir cazibe merkezi yaratmada destinasyon pazarlamasının önemini artırmaktadır. Bu gelişmeyi kavrayan ve uygulayabilen kentler, bölgeler veya ülkeler sahip oldukları çekicilik unsurlarını doğru anlamda kullanarak fark yaratabilmeye çalışmaktadır (Çiçek ve Pala, 2017: 26). Destinasyonların kendine has farklı tarihi, kültürel, sosyal cazibe unsurları bulunmaktadır. Şengül ve Türkay (2016: 3) yapmış oldukları çalışmada destinasyonların sahip oldukları cazibe unsurlarından birinin de yöresel mutfak kültürleri olduğunu açıklamışlardır. Mutfak son zamanlarda turizm hareketi içinde dikkat çeken unsurlar arasında yer almaktadır. Her destinasyon, turistlere sahip olduğu çekiciliklerinin yanı sıra bölgede yaşayan insanların mutfak kültürlerini de deneyimleme imkânı sunmaktadır.

\subsection{Benzersizlik}

Kaplan'a (1995) göre, destinasyon çekiciliğgi; benzersiz bir şeyin istem dişı dikkat çekmesi ve turistlerin büyüleyici bir deneyim süreciyle karşılaşarak bir destinasyonun benzersizliğini keşfetmesi olarak açıklamaktadır. Echtner ve Ritchie (1993), benzersizliğin destinasyon imajının anahtar ölçüsü olduğunu, destinasyonlar arasındaki farklılıkları şekillendirdiğini ve turistlerin bir destinasyon hakkında neyin özel olduğunu anlamalarını sağladığını belirtmişlerdir. Destinasyonun benzersizliği, 
turistlerin günlük hayatta deneyimlenemeyen özel bir şey deneyimlemelerini sağlayarak destinasyon çekiciliklerini arttırmaktadır.

\subsection{Uygunluk}

Uygunluk, turistlerin benlik imajları ile destinasyon arasındaki uyuma ilişkin sübjektif algıları olarak tanımlanabilir. Turistlerin destinasyondaki deneyimlerinin kendi benlik imajlarıyla uyumlu olduğunu hissetmeleri ile ilgilidir (Karadamar vd., 2018: 13). Sirgy ve Su (2000) turistlerin kendileri ile destinasyon arasındaki uyumluluğunun destinasyon seçimlerini önemli ölçüde etkilediğini göstermişlerdir. Ayrıca ziyaret edilen destinasyonun turistlerin kişilik özelliklerine, beğenilerine uygun olması turistlerin o destinasyon ile aralarında bağ kurarak orayı yeniden ziyaret etmelerini sağlamaktadır.

\subsection{Sicakkanlılık}

Samimi davranışlar; sıcakkanlı olma, empatik, hoş sohbet, cana yakın olma, enerjik, insancıl, heyecanlı, konuşkan, iyimser olma gibi duyguları kapsar (Kozak ve Güçlü, 2008: 43). Bir destinasyonda yerel halkın turistlerle olan etkileşimi göz önünde bulundurulduğunda yerel halkın turistlere karşı kibar, saygılı, sıcakkanlı olması turizmin başarısı açısından gereklidir. Dolayısıyla yerel halkın turizme yönelik tutum ve algıları ile bunların yaşam kalitelerinin üzerindeki etkileri sürekli olarak değerlendirilmesi gereken bir konudur (Ayazlar ve Ayazlar, 2016: 1452). Ayrıca bir destinasyonda çalışan personelin samimi ve sıcakkanlı olması, turistlerin kendilerini orada rahat ve güvende hissetmelerini sağlayarak o destinasyona olan talebi artırmaktadır.

\section{DESTINASYON MARKA KİMLİĞí}

Marka kimliği; ürünün tüketicilerin gözünde nasıl algılandıklarının özü olarak ifade edilmektedir. Güçlü bir marka kimliği, ürünün değerini ve önemini artıran bir olgu olarak görülmektedir (Aaker, 1995: 209). Marka kimliğini oluşturan unsurlar; marka ismi, sembol, logo, slogan, renkler, ambalajlama / paketleme olarak sıralanabilir (İnce ve Uygurtürk, 2019: 226). De Cahernatony (1999) çalışmasında marka kimliği unsurları olarak; marka vizyonu, marka kültürü, marka konumlandırması, marka kişiliği, marka unsurlarını belirlemiştir. Florek vd. (2006) çalışmalarında, Klage'nin (1991) işletmeler için belirlediği marka kimliği unsurlarını; destinasyon tasarımı, destinasyon davranışı ve destinasyon iletişimi olarak inceleyerek destinasyonlar için uyarlamışlardır.

Tsaur vd. (2016) destinasyon marka kimliğini ölçmek için geliştirdikleri ölçekte, marka kimliği unsurlarını; destinasyon imajı (destination image), destinasyon kalitesi (destination quality), destinasyon kişiliği (destination personality), destinasyon farkındalığg (destination awareness) ve destinasyon kültürü (destination culture) olarak belirlemişlerdir. Destinasyon marka kimliği unsurları aşağıda incelenmektedir: 


\section{1. Destinasyon İmajı}

Marka imajı; ürün varlığının ve marka kişiliğinin yansıması olan, tüketicilerin düşüncelerinde, hislerinde ve beklentilerinde marka ile ilgili inançlarını gösteren, satın alma kararında etkili olan, markanın insanların zihnindeki algılanış düzeyidir (Gülmez ve Dörtyol, 2013: 208). Destinasyon imajı ise, bir kişinin veya bir grup insanın bir destinasyon hakkındaki inanç, fikir ve izlenimlerinden oluşmaktadır (Özdemir, 2019: 66). İmaj, zihnin algılaması ve analitik süreç ile ilgili iken, imaj oluşumu, iç ve dış faktörlerden etkilenen bir unsurdur. İç faktörler, müşterinin kişisel özelliklerini kapsamakta, dış faktörler ise ürün özelliklerini ve imaj yaklaşımlarını içermektedir (Koubaa, 2008: 140). Turizm sektöründe olumlu bir destinasyon imajı, müşterilerin satın alma tercihlerini olumlu yönde etkilemekte ve bu destinasyondaki işletmelerin rekabet gücünü artırmaktadır (Gül vd., 2019: 58). Destinasyon imajı ayrica turistlerin beklentilerini, ziyaret niyetlerini, memnuniyetini, destinasyondaki davranışını ve genel destinasyon deneyimini de şekillendirmektedir.

\section{2. Destinasyon Kalitesi}

Pike vd. (2010), turizm ve ağırlama endüstrisinde, destinasyon kalitesini; bir destinasyonun altyapısı, ağırlama hizmeti, konaklama konforu gibi hizmetler üzerine algıladıkları kalite ile ilgili olduğunu açıklamışlardır. Algılanan kalite, niyet edilen amaca uygun şekilde bir mal veya hizmetin tüm kalite ve üstünlükleri üzerinde tüketicilerin algıları olarak tanımlamaktadır. Bir destinasyon için algılanan kalite ise, tüketicilerin o destinasyon ile ilgili beklentilerin karşılanması ya da aşılması olarak görülmektedir (Çetinsöz ve Karakeçili, 2018: 129). Destinasyonlarda üretilen tüm ürün ve hizmetlerin kalitesi, destinasyon kalitesinde belirleyicidir. Turizm destinasyonlarında sunulan ürün ve hizmetler, destinasyonda yer alan tüm turizm işletmeleri tarafından sunulan ürün ve hizmetleri kapsamaktadır. Dolayısıyla her işletme destinasyon kalitesinden sorumludur. Çünkü destinasyonda turizm işletmelerince sunulan ürün ve hizmetlerin kalitesi, genel destinasyon kalitesini oluşturmaktadır (Güneş, 2018: 425).

\subsection{Destinasyon Kişiliği}

Marka kişiliği, Aaker (1997) tarafından "Bir markayla bağdaştırılan insani özelliklerin bir kümesi" olarak tanımlanmıştır. Bu tanıma göre markalar ve tüketiciler arasında bir bă̆ kurulmaktadır. Markaların canlı ve hayat dolu olduğu düşünülmektedir (Ülkü ve Bişkin, 2020: 128). Zhang ve Bai (2011), marka kişiliğinin işlevsel niteliklerl karşılaştırıldığında ürünün kültürünü, duygusunu, değerini ve sembolik anlamlarını taşıdığını ifade etmektedirler. Destinasyonların kişileştirilmesi, marka değerinin anlaşılmasına ve gelişimine yardımcı olur. Dolayısıyla destinasyonların sahip olduğu özelliklerin çok iyi belirlenmesi ve rekabet üstünlüğü sağlayan yönlerinin öne çıkarılması için destinasyon kişiliklerinin de tespit edilmesi gerekmektedir (Dülgeroğlu ve Atay, 2019: 149). 


\subsection{Destinasyon Farkındalığı}

Marka farkındalığı; markanın tanınması, pazarda veya reklamda tüketici tarafından görülmesi ve tüketicinin markayı gördüğünün farkında olması şeklinde tanımlanabilmektedir (Söylemez ve Duygum, 2020: 261). Marka farkındalığı bir markanın adının, logosunun, ambalajının, karakterinin, sunduğu faydaların, biçimsel ve içeriksel işlevlerin kategori gereksinimi ile birleşimlerinden oluşur (Öcel, 2020: 261). Günümüzde yoğun rekabet içeren pazarlarda marka kalabalı̆̆ı içerisinde kaybolmaya yönelik olarak marka farkındalığı oluşturmanın markalara fayda sağlayacağı düşünülmektedir. Ayrıca marka farkındalığı, tüketicilerin satın alma kararları ve tüketim tercihleri üzerinde etkili olan bir olgudur (Torlak vd., 2014: 149). Destinasyonlarda ise destinasyonların benzerlerinden ayrılmak üzere yürüttükleri her türlü planlama, strateji, faaliyet ve bir destinasyonun markası ile ilgili turistlerin sahip oldukları olumlu veya olumsuz bilgilerin tamamı destinasyon marka farkındalığı olarak ele alınmaktadır (Ünal, 2020: 14). Turistlerin seyahat davranışlarında, destinasyon hakkında sahip oldukları bilginin etkisi bulunmaktadır. Bir turizm destinasyonu ile ilgili turistlerin nezdinde olumlu algı oluşturabilmek ve farkındalık yaratabilmek destinasyon çekiciliği oluşturmak açısından oldukça önemlidir (Şengül ve Türkay, 2018: 225).

\section{5. Destinasyon Kültürü}

Kültür, toplumdaki farklı davranış kalıplarının birikimini temsil etmektedir. Ekonomik, yasal, politik ve teknolojik yönler olarak adlandırılan farklı makro-çevresel unsurların tümü, farklı davranış kalıplarını etkiler. Tarihsel olarak, antropolojinin ortaya çıkmasıyla birlikte, kültür terimi, bir toplumda yaşayanların gelenekleri ve davranış kalıplarıyla ilişkilendirilmiştir (Kumar ve Dhir, 2020: 2).

Bir destinasyonda yaşayanların gelenek görenekleri, inançları, yaşayış tarzları, tutamları o destinasyonun kültürünü oluşturur. Destinasyonların kültürel özellikleri, turist memnuniyetini etkilemektedir. Kültürel ve tarihi mekanlar, festivaller, sanat gibi marka varlıkları, destinasyon marka imajının önemli belirleyicileridir. Turizm faaliyetleri, bir destinasyonun kültürü üzerinde olumlu etkiler yaratabilirken kültürel ve tarihi alanların korunmaması gibi olumsuz etkiler de yaratabilir (Lee ve Xue, 2020: 394). Kültür, destinasyonlara olumlu bir imaj sunmakta daha fazla turist çekmekte ve daha fazla iş için yeni kapılar açmaktadır. Ayrıca destinasyonların sahip olduğu kültürel miras, turistleri etkilemekte ve o destinasyonları seçmelerinde belirleyici rol almaktadır (Herlina, 2020: 27).

\section{ARAŞTIRMA YÖNTEMI}

Bu araştırmada Liu vd. (2017) tarafından geliştirilen destinasyon çekiciliği ölçeği ve Tsaur vd. (2016) tarafından geliştirilen destinasyon marka kimliği ölçeğinin geçerlik ve güvenilirliklerini test etmek, faktör yapılarını belirlemek ve Türkçe uyarlamasının kullanılabilirliğini ortaya koymak amaçlanmaktadır. 
Araştırmanın ana kütlesini Türkiye'deki destinasyon merkezlerini ziyarete gelen turistler oluşturmaktadır. Ada destinasyonlarının önemi son yıllarda hem dünyada hem de Türkiye'de her geçen gün artmaktadır. Gökçeada yüz ölçümü bakımından Türkiye'nin en büyük adası olup, eşsiz doğası, alternatif turizm imkanları ile turistlerin cazibe merkezi haline gelmeye başlamıştır. Bu nedenle yapılan araştırmada ada turizmi ele alınarak Gökçeada'ya gelen turistler örneklem olarak seçilmiştir.

Araştırma öncesinde ölçeğin güvenilirliğini test etmek amaçlı bir ön test uygulanır. Ön-testin nedeni ölçeğin önceki aşamalarda gözden kaçmış olabilecek kimi eksiklerin muhtemel cevaplayıcılarla aynı özellikleri taşıyan küçük veri gurubu üzerinde denenmesidir. Ön-test verileri betimsel analiz, iç tutarlılık analizi ve madde-toplam korelasyonu analizine tabi tutulmakta ve böylece ölçeğin güvenilirliğini düşüren ifadeler gözden geçirilerek, gerekirse elenmektedir (Erdemir, 2018: 13). Bu nedenle araştırma öncesinde Gökçeada'ya gelen 30 turist üzerinde ön test uygulaması gerçekleştirilmiştir. Veri toplama aracı olarak anket formu kullanılmıştır. Anketin birinci bölümünde destinasyon çekiciliği ölçeği yer almaktadır. Ölçekte, destinasyon çekiciliği unsurları çok faktörlü bir kavram olarak ele alınarak; gizem, zenginlik, cazibe, benzersizlik, uygunluk ve sıcakkanlılık olarak açıklanmıştır. Araştırma öncesinde yapılan ön test aşamasında ölçeğin güvenirliği test edilmiştir. Destinasyon çekiciliği ölçeğinde sıcakkanlılık faktörü altındaki maddeler yeterli faktör yükü değeri taşımadığı için (FY <0,45; Karagöz, 2019: 676) araştırmadan araştırmadan çıkarılmış ve ölçek, gizem, zenginlik, cazibe, benzersizlik ve uygunluk olmak üzere beş faktör olarak değerlendirilmiştir. Ölçek 25 maddeden oluşan 5'li likert tipi ölçektir. Anketin ikinci bölümünü 32 maddelik 5'li likert tipi olarak hazırlanan destinasyon marka kimliği ölçeği oluşturmaktadır. Destinasyon marka kimliği ölçeği; destinasyon imajı, destinasyon kalitesi, destinasyon kişiliği, destinasyon farkındalığı ve destinasyon kültürü olarak beş faktör altında incelenmiştir. Ölçeklerin yapı geçerliğini belirlemek için açıklayıcı faktör analizi, temel bileşenler analizi ve varimax döndürme tekniği kullanılmıştır. Özdeğeri 1'den büyük olan faktörler dikkate alınarak ölçeğin kaç faktörden meydana geldiği ve maddelerin faktör yükleri belirlenmiştir. Açıklayıcı faktör analizi ile belirlenen faktör yapıları doğrulayıcı faktör analizine tabi tutulmuştur. Doğrulayıcı faktör analizi sürecinde öncelikle modele ilişkin ki-kare $\left(\chi^{2}\right)$ değerinin serbestlik derecesi ve bir dizi uyum iyiliği indeksleri değerlerinin yeterlilik düzeyleri incelenmiştir. Son olarak Türkçeye uyarlanan ve faktör yapısı belirlenen faktörler ve alt faktörler için ölçek maddelerinin birbirleriyle tutarlılığını test edebilmek amacıyla, güvenirlik çalışması kapsamında alt faktörleri ve ölçeklerin tümü için Cronbach Alfa $(\alpha)$ değerleri hesaplanmıştır.

\section{ARAŞTIRMA BULGULARI}

Araştırma için hazırlanan anket formu, Gökçeada'ya tatil amaçlı gelen iki ayrı örneklem üzerinde uygulanmıştır. İki ayrı örneklemin kullanılmasındaki amaç bir örneklemde elde edilen bulguların, 
farklı bir zamanda ayrı bir örneklem grubunda da denenerek, bulguların genellenebilirliğinin arttırılmasıdır (Basım ve Beğenirbaş, 2012: 81). Birinci araştırma grubu (n1) 220 turistten oluşmaktadır. Birinci araştırma grubuna açıklayıcı faktör analizi (AFA) uygulanarak ölçeklerin yapı geçerlikleri incelenmiştir. Aynı dönemde Gökçeada’ya gelen (n2) 160 kişiden oluşan araştırma grubuna doğrulayıcı faktör analizi (DFA) çalışması yapılmıştır. Ölçeklerin model uyum indeksleri incelenerek güvenirliği hesaplanmıştır.

\subsection{Katılımcıların Demografik Özellikleri}

Yapılan araştırmalar sonucunda turistlerin demografik özelliklerinden; yaşları, cinsiyetleri, medeni durumları, eğitim düzeyleri, kişisel gelirleri, meslekleri ve ikamet ettikleri iller belirlenmiş, her bir değişkene ait, frekans ve yüzde değerleri incelenmiştir. Bu değerler, Tablo 1'de gösterilmektedir.

Tablo 1. Birinci ve ikinci Veri Setinde Katılımcıların Demografik Özellikleri

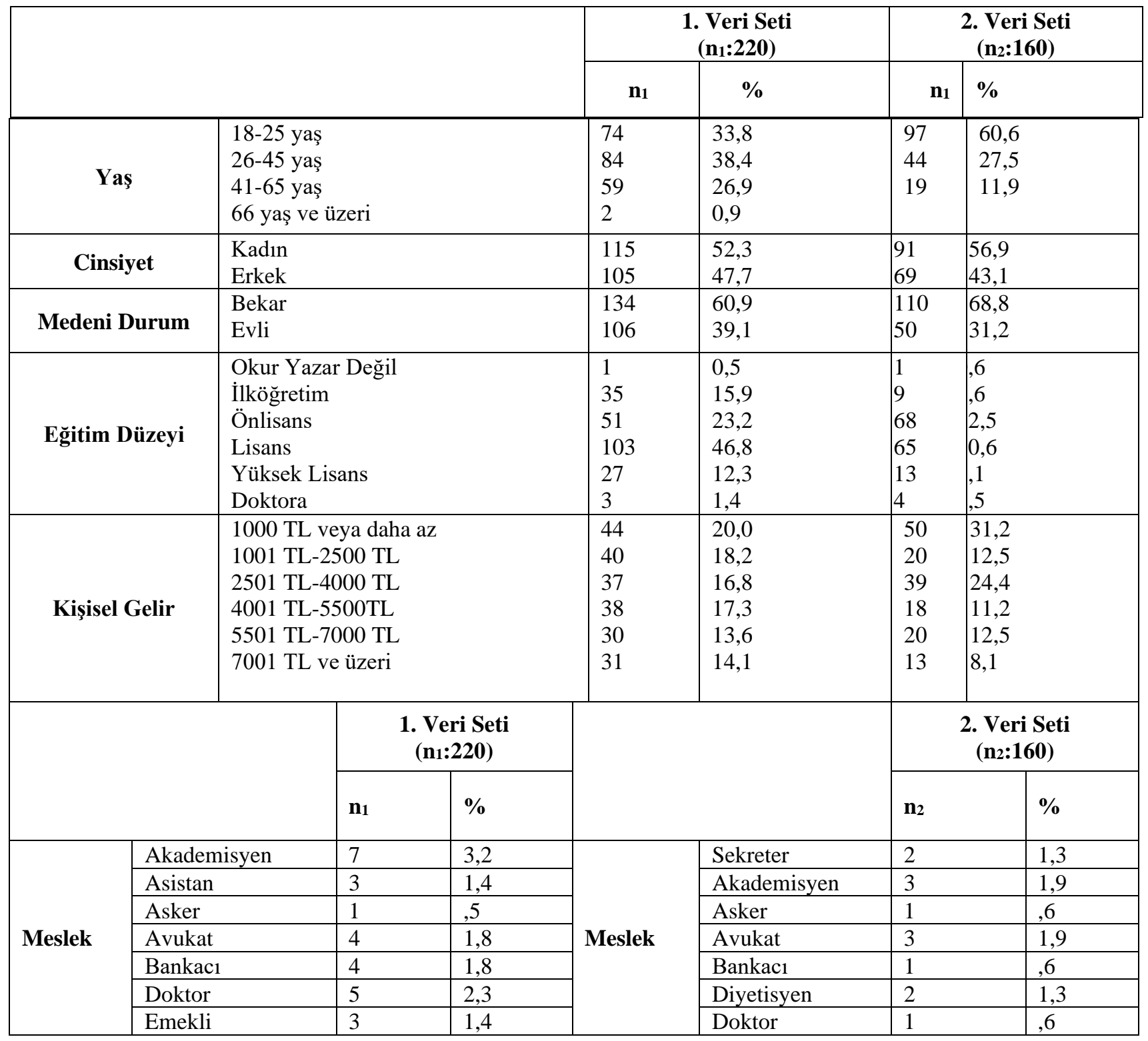




\begin{tabular}{|c|c|c|c|c|c|c|c|}
\hline & Esnaf & 5 & 2,3 & & Eczacı & 3 & 1,9 \\
\hline & Ev Hanımı & 10 & 4,5 & & Emekli & 3 & 1,9 \\
\hline & Fotoğrafç1 & 1 &, 5 & & Esnaf & 2 & 1,3 \\
\hline & Gastronom & 3 & 1,4 & & Ev Hanımı & 4 & 2,5 \\
\hline & Gazeteci & 4 & 1,8 & & Gastronom & 3 & 1,9 \\
\hline & Gida Teknikeri & 3 & 1,4 & & Hemşire & 3 & 1,9 \\
\hline & Hemşire & 4 & 1,8 & & İşçi & 4 & 2,5 \\
\hline & İşçi & 7 & 3,2 & & Memur & 7 & 4,4 \\
\hline & Kaptan & 1 &, 5 & & Muhasebeci & 9 & 5,6 \\
\hline & Laborant & 1 & 5 & & Öğrenci & 61 & 38,1 \\
\hline & Memur & 11 & 5,0 & & Öğretmen & 8 & 5,0 \\
\hline & Mimar & 6 & 2,7 & & Psikolog & 3 & 1,9 \\
\hline & Muhasebeci & 7 & 3,2 & & Satış Danışmanı & 6 & 3,8 \\
\hline & Mühendis & 16 & 7,3 & & Sekreter & 1 & ,6 \\
\hline & Öğrenci & 60 & 27,3 & & Serbest Meslek & 17 & 10,6 \\
\hline & Öğretmen & 24 & 10,9 & & Teknisyen & 4 & 2,5 \\
\hline & Özel Sektör & 2 & ,9 & & Turizmci & 1 & 6 \\
\hline & Psikolog & 1 &, 5 & & Tüccar & 2 & 1,3 \\
\hline & Ressam & 1 &, 5 & & Yönetici & 6 & 3,8 \\
\hline & Satış Danışmanı & 8 & 3,6 & & & & \\
\hline & Sekreter & 2 & ,9 & & & & \\
\hline & Serbest Meslek & 6 & 2,7 & & & & \\
\hline & Sosyolog & 1 &, 5 & & & & \\
\hline & Şöför & 1 &, 5 & & & & \\
\hline & & & $\begin{array}{l}\text { i Seti } \\
\text { 220) }\end{array}$ & & & & $\begin{array}{l}\text { Seti } \\
\text { 60) }\end{array}$ \\
\hline & & $\mathbf{n}_{1}$ & $\%$ & & & $\mathbf{n}_{2}$ & $\%$ \\
\hline & Adana & 2 & 9 & & Ardahan & 1 & 6 \\
\hline & Ankara & 4 & 1,8 & & Artvin & 2 & 1,3 \\
\hline & Antalya & 1 &, 5 & & Balıkesir & 3 & 1,9 \\
\hline & Aydin & 6 & 2,7 & & Bursa & 5 & 3,1 \\
\hline & Balıkesir & 2 & ,9 & & Çanakkale & 24 & 15,0 \\
\hline & Bursa & 7 & 3,2 & & Denizli & 1 & 6 \\
\hline & Çanakkale & 32 & 14,5 & & Edirne & 1 & 6 \\
\hline & Edirne & 1 &, 5 & & Eskişehir & 4 & 2,5 \\
\hline & Eskişehir & 1 &, 5 & & Gaziantep & 1 & 6 \\
\hline & Gaziantep & 1 & 5 & & Gelibolu & 1 & 6 \\
\hline & Hatay & 3 & 1,4 & & Hatay & 2 & 1,3 \\
\hline & İstanbul & 99 & 45,0 & & İstanbul & 66 & 41,3 \\
\hline & İzmir & 21 & 9,5 & & İzmir & 8 & 5,0 \\
\hline & Kurklareli & 2 & ,9 & & Kars & 1 & ,6 \\
\hline & Kocaeli & 3 & 1,4 & & Kırklareli & 1 & ,6 \\
\hline & Ordu & 1 & 5 & & Kocaeli & 3 & 1,9 \\
\hline & Rize & 2 & 9 & & Manisa & 1 & 6 \\
\hline $\begin{array}{l}\text { Ikamet } \\
\text { Edilen İI }\end{array}$ & Tekirdağ & 28 & 12,7 & $\begin{array}{l}\text { Íkamet } \\
\text { Edilen İI }\end{array}$ & Muğla & 3 & 1,9 \\
\hline & Trabzon & 3 & 1,4 & & Ordu & 1 & ,6 \\
\hline & Zonguldak & 1 &, 5 & & Sakarya & 2 & 1,3 \\
\hline & Adana & 2 & ,9 & & Samsun & 3 & 1,9 \\
\hline & Ankara & 4 & 1,8 & & Tekirdağ & 26 & 16,3 \\
\hline & Antalya & 1 &, 5 & & & & \\
\hline & Aydin & 6 & 2,7 & & & & \\
\hline & Balıkesir & 2 & ,9 & & & & \\
\hline & Bursa & 7 & 3,2 & & & & \\
\hline & Çanakkale & 32 & 14,5 & & & & \\
\hline & Edirne & 1 &, 5 & & & & \\
\hline
\end{tabular}




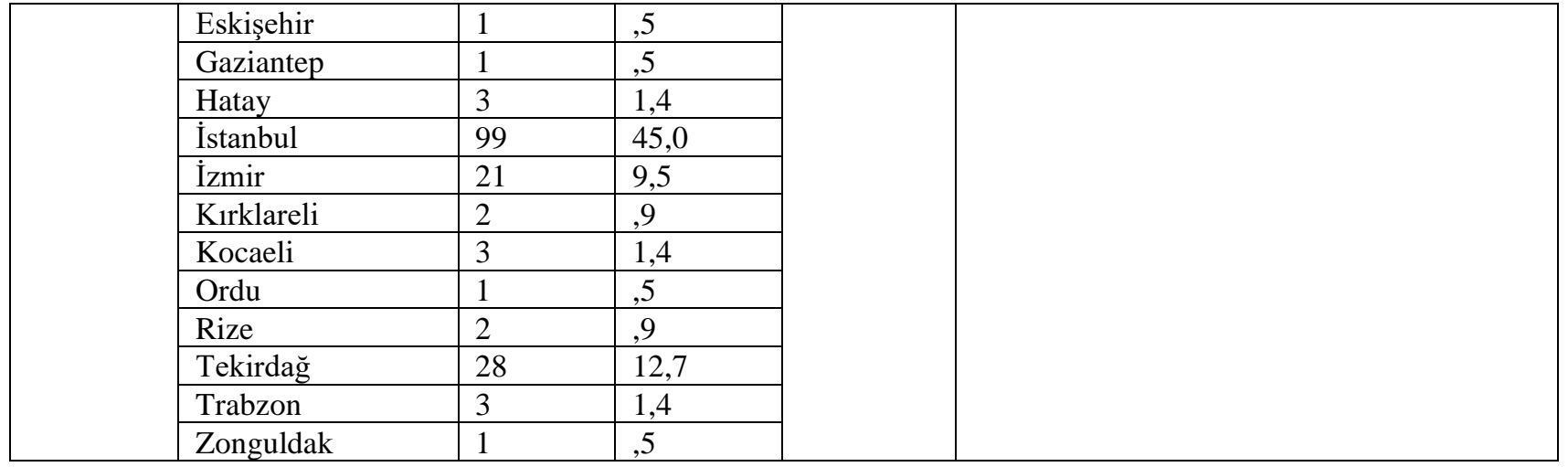

\subsection{Açıklayıcı Faktör Analizi}

Açıklayıcı (açımlayıcı, keşfedici) faktör analizi (AFA); çok sayıdaki değişkeni, belirli sayıda gruplara ayırarak, her bir grubun içindeki değişkenler arasındaki ilişkiyi maksimum; gruplar arasındaki ilişkiyi ise minimum yaparak, grupları yeni değişkenlere dönüştüren bir analiz türüdür (Karagöz, 2019: 671). Faktör analizinin belirli hedefleri; gözlenen değişkenler arasındaki korelasyon kalıplarını özetlemek, büyük sayıdaki gözlenen değişkenleri daha az sayıda faktörlere dönüştürmek, gözlenen değişkenleri kullanarak temel işlemler için operasyonel bir tanım (bir regresyon denklemi) oluşturmak ya da süreçlerin doğası hakkındaki bir teoriyi test etmektir (Tabachnick ve Fidell, 2013: 612). Araştırmacılar faktör analizi kullanarak veride yer alan bir dizi faktörü veya faktörün teorik açıdan yorumlanabilir olup olmadığını belirleyebilmektedir. Diğer taraftan AFA, p değişkenli bir olayda birbirleri ile ilişkili değişkenleri bir araya getirerek, az sayıda ancak önemli, yeni ilişkisiz değişkenler bulmayı hedeflemektedir (Çokluk vd., 2016: 185).

Tablo 2. Destinasyon Çekiciliği Ölçeği Açıklayıcı Faktör Analiz Tablosu

\begin{tabular}{|l|l|l|l|}
\hline Ölçekler & \multicolumn{1}{|c|}{$\begin{array}{c}\text { Faktör } \\
\text { Yükleri }\end{array}$} & $\begin{array}{c}\text { Varyans } \\
\mathbf{\%}\end{array}$ & Özdeğer \\
\hline $\begin{array}{l}\text { Destinasyon Çekiciliği (DÇ) } \\
\text { KMO: 0,948; } \\
\text { Bartlett'in Küresellik Testi; }(\boldsymbol{\chi 2}=\mathbf{4 1 0 8 , 6 3 4 ; ~ d f = 3 0 0 ; ~ p = 0 , 0 0 0 )}\end{array}$ & & \\
\hline Uygunluk (UYG) & & $\mathbf{2 9 , 9 1 5}$ & $\mathbf{7 , 4 7 9}$ \\
\hline UYG23: Burası gerçekten kişisel tarzımın bir kısmını yansıtıyor. & 0,828 & & \\
\hline UYG21: Burası hayat tecrübelerimle ve tarzımla uyumludur. & 0,828 & & \\
\hline UYG24: Burası gerçek beni yansıtıyor. & 0,825 & & \\
\hline UYG25: Bu ada benimle ve yapmak istediklerimle uyumludur. & 0,801 & & \\
\hline CZB14: Burada daha uzun kalmak isterim. & 0,791 & & \\
\hline UYG22: Buradaki atmosfer, sevdiğim tarzda. & 0,780 & & \\
\hline CZB13: Adada güzel duygular hissediyorum. & 0,705 & & \\
\hline CZB12: Adada sunulan duyusal deneyimler beni cezbediyor. & 0,610 & & \\
\hline CZB11: Ruh halimi burada değiştirebilirim. & 0,589 & & \\
\hline ZNG9: Adada kalırken sıkılmadım. & 0,542 & & \\
\hline ZNG8: Ada bana farklı duyular ve deneyimler sağlıyor. & 0,513 & & \\
\hline
\end{tabular}




\begin{tabular}{|l|l|l|l|}
\hline Benzersizlik (BNZ) & & $\mathbf{2 1 , 1 2 2}$ & $\mathbf{5 , 2 8 0}$ \\
\hline BNZ18: Bu adanın diğerlerinden farklı olduğunu düşünüyorum. & 0,831 & & \\
\hline BNZ17: Ada görsel açıdan diğer adalardan farklı görünüyor. & 0,798 & & \\
\hline BNZ16: Burası eşsiz bir tarz yaratıyor. & 0,641 & & \\
\hline BNZ19: Adanın kendine has yerel özellikleri var. & 0,635 & & \\
\hline GZM3: Ada gizemli bir yer. & 0,591 & & \\
\hline BNZ15: Burası benzersiz deneyimler sunuyor. & 0,557 & & \\
\hline GZM1: Adayı gezerken buraya olan merakım arttı. & 0,532 & & \\
\hline ZNG6: Adayı ziyaret ederken farklı duygular yaşayabilirim. & 0,521 & & \\
\hline GZM2: Ada, keşif yapmak için kayda değer bir yer. & 0,500 & & \\
\hline ZNG5: Adada keşfetmeye değer birçok yer var. & 0,495 & & \\
\hline Zenginlik (ZNG) & & $\mathbf{1 1 , 9 3 1}$ & $\mathbf{2 , 9 8 3}$ \\
\hline ZNG7: Ada çeşitli eğlence imkânları ve faaliyetler sunmaktadır. & 0,599 & & \\
\hline GZM4: Ada günlük hayatımdan farklı deneyimler sunuyor. & 0,596 & & \\
\hline C10: Adada, tadını çkarabilecek birçok yer bulabilirim. & 0,591 & & \\
\hline B20: Adanın özel temalı alanları var. & 0,513 & & \\
\hline Toplam & & $\mathbf{6 2 , 9 6 8}$ & \\
\hline
\end{tabular}

Faktör Çıkarma Yöntemi: Temel Bileşen Analizi.

Döndürme Yöntemi: Kaiser Normalizasyonu ile Varimax. Rotasyon 5 iterasyonda yakınsadı.

Çalışma grubundan elde edilen verilerin açıklayıcı faktör analizine uygun olup olmadığı KaiserMeyer-Olkin (KMO) ve Barlett testi ile açıklanabilir. Kaiser-Meyer Olkin değerinin yüksek olması, ölçekteki her bir değişkenin, diğer değişkenler tarafından mükemmel bir şekilde tahmin edilebileceği anlamına gelir. KMO testinin değeri 0 ile 1 aralığında olmalıdır. KMO, testinde bulunan değer 0,50'nin altında ise kabul edilemez. 0,50 zayıf; 0,60 orta; 0,70 iyi; 0,80 çok iyi; 0,90 mükemmeldir (Tavşancıl, 2002:50). Bu doğrultuda Tablo 2 incelendiğinde destinasyon çekiciliği ölçeği için yapılan KMO testi sonucu bulunan katsayı $(0,948)$ olduğundan verilerin faktör analizi için “mükemmel” düzeyde uygun olduğu görülmektedir. Ayrıca Bartlett küresellik testi sonuçları incelendiğinde ki-kare $(\chi 2=4108,634$; $\mathrm{df}=300 ; \mathrm{p}<0,000$ ) değerinin anlamlı olduğunu göstermektedir. $\mathrm{P}$ (sig) $0,000<0,005$ olduğundan Bartlett küresellik testi sonucu da anlamlı olarak tespit edilmiştir. Yani değişkenler arasında yüksek korelasyon mevcuttur ve veriler çoklu normal dağılımdan gelmiş demektir. Elde edilen her iki bulguya göre veriler faktör analizi için uygundur (Karagöz, 2019: 680).

Faktör yükleri, her bir faktör oluşmasında değişkenlerin, maddelerin katkılarını, ağırlıklarını belirtir. Faktör yüklerinin genelde 0,50 veya daha yüksek olması uygun olmakla birlikte 0,45 olmasının yeterli olacağını hatta ölçekteki madde sayısı az ise 0,30 olabileceği söylenmektedir. Faktör yük değerlerinin $0,45^{\prime}$ in $(0,30-0,50)$ altında olan maddeler analizden çıkarılmalıdır. Çıkarılma işlemi yapılırken değeri en düşük madde ile başlanmalıdır. En düşük değer analizden çıkarıldıktan sonra analiz tekrar edilmelidir. Bu işlem 0,45’ten küçük olan bütün maddeler analizden çıkarılana kadar işlem tekrar eder (Karagöz, 2019: 676). Yapılan AFA sonucunda Tablo 2'ye göre faktör yüklerinin 0,45 ve üzerinde 
değerler aldığı görülmektedir. Bu nedenle ölçekteki maddelerin analizden çıkarılmaması uygun görülmüş ve tüm maddelerin 3 faktör altında dağılım gösterdiği gözlenmiştir. 1. Faktör: Uygunluk (UYG), 2. Faktör: Zenginlik (ZNG), 3. Faktör: Benzersizlik (BNZ) olarak adlandırılmıştır. Faktör sayısının belirlenmesinde özdeğer istatistiğinden yararlanılmaktadır. Özdeğer istatistiği 1'e eşit veya daha büyük olan faktörler anlamlı kabul edilmektedir. Söz konusu değer 1'den küçük olduğu taktirde faktörler dikkate alınmamaktadır (Sayar vd., 2020: 5). Özdeğerler, faktörlerce açıklanan varyansı hesaplamada ve faktör sayısına karar vermede kullanılmaktadır. Dolayısıyla faktör analizinde sadece özdeğerleri 1 ve 1 'in üzerinde olan faktörler kararlı olarak kabul edilir. Özdeğer yükseldikçe, faktörün açıkladığı varyans da yükselir (Kayapınar, 2018: 589). Literatürde genellikle toplam varyans açıklama yüzdesinin 60 ve üzeri olması istenmektedir (Alpar, 2013: 296). Açıklanan toplam varyans yeterli büyüklükte ise oluşturulan ölçeğin yapı geçerliliği var demektir (Karagöz, 2019: 674). Faktörlerin özdeğerleri; uygunluk faktörü için 7,479; benzersizlik faktörü için 5,280 ve cazibe faktörü için 2,983 olarak tespit edilmiştir. Faktörlerin toplam varyans açıklama oranları; uygunluk faktörü için \%29,915; benzersizlik faktörü için \%21,122 ve cazibe faktörü için \%11,931 olarak tespit edilmiştir. Destinasyon çekiciliği ölçeğinin toplam varyans açıklama oranı \%62,968 olarak bulunmuştur.

Tablo 3. Destinasyon Marka Kimliği Ölçeği Açıklayıcı Faktör Analizi Tablosu

\begin{tabular}{|c|c|c|c|}
\hline Ölçekler & $\begin{array}{c}\text { Faktör } \\
\text { Yükleri }\end{array}$ & $\begin{array}{c}\text { Varyans } \\
\%\end{array}$ & Özdeğer \\
\hline \multicolumn{4}{|l|}{$\begin{array}{l}\text { Destinasyon Marka Kimliği } \\
\text { KMO: 0,924; } \\
\text { Bartlett'in Küresellik Testi; }(\chi 2=5440,709 ; \mathrm{df}=171 ; p=0,000)\end{array}$} \\
\hline Destinasyon Kalitesi (DKA) & & 13,626 & 4,561 \\
\hline $\begin{array}{l}\begin{array}{l}\text { DKA39: Ziyaret edilen diğer destinasyonlarla karşılaştırıldığında, } \\
\text { adadaki turizm mekanları son derece temizdir. }\end{array} \\
\end{array}$ & 0,706 & & \\
\hline $\begin{array}{l}\text { DKKL57: Ziyaret edilen diğer ülkelerle karşılaştırıldığında, adada } \\
\text { zengin yerli sanatlar (örneğin opera, el sanatları) bulunmaktadır. }\end{array}$ & 0,687 & & \\
\hline $\begin{array}{l}\text { DKA38: Ziyaret edilen diğer ülkelerle karşılaştırıldığında, adada } \\
\text { yüksek kaliteli altyapı (ulaşım, kamu tesisleri) hizmetleri } \\
\text { bulunmaktadır. }\end{array}$ & 0,669 & & \\
\hline $\begin{array}{l}\begin{array}{l}\text { DK40: Ziyaret edilen diğer destinasyonlarla karşılaştırıldığında, adada } \\
\text { turizm ortamının yüksek seviyede güvenliği bulunmaktadır. }\end{array} \\
\end{array}$ & 0,606 & & \\
\hline $\begin{array}{l}\begin{array}{l}\text { DKA37: Ziyaret edilen diğer destinasyonlarla karşılaştırıldığında, } \\
\text { adada yüksek kalitede konaklama tesisleri vardır. }\end{array} \\
\end{array}$ & 0,581 & & \\
\hline $\begin{array}{l}\text { Dİ36: Ziyaret edilen diğer destinasyonlarla karşılaştırıldığında, adada } \\
\text { çeşitli festival etkinlikleri ve aktiviteleri bulunmaktadır. }\end{array}$ & 0,574 & & \\
\hline $\begin{array}{l}\text { DKA43: Ziyaret edilen diğer destinasyonlarla kıyaslandığında, adada } \\
\text { iletişimle ilgili az sorun yaşanmaktadır. }\end{array}$ & 0,550 & & \\
\hline $\begin{array}{l}\text { DKL54: Ziyaret edilen diğer destinasyonlarla karşılaştırıldığında, adalı } \\
\text { insanlar karakteristik bir yaşam tarzı sergilemektedir. }\end{array}$ & 0,531 & & \\
\hline Destinasyon Kültürü (DKL) & & $\mathbf{1 1 , 0 5 1}$ & 4,440 \\
\hline $\begin{array}{l}\begin{array}{l}\text { DKL55: Ziyaret edilen diğer destinasyonlarla kıyaslandığında adadaki } \\
\text { tarihi yapılar karakteristiktir. }\end{array} \\
\end{array}$ & 0,772 & & \\
\hline $\begin{array}{l}\text { Dİ26: Ziyaret edilen diğer destinasyonlarla karşılaştırıldığında adada } \\
\text { güzel görüntüler var. }\end{array}$ & 0,742 & & \\
\hline $\begin{array}{l}\text { Dİ33: Ziyaret edilen diğer destinasyonlarla karşılaştırıldığında, adada } \\
\text { ilginç kültürel cazibe alanları var. }\end{array}$ & 0,699 & & \\
\hline
\end{tabular}




\begin{tabular}{|c|c|c|c|}
\hline $\begin{array}{l}\text { Dİ2: Ziyaret edilen diğer destinasyonlarla karşılaştırıldığında, adada } \\
\text { ilginç tarihi yerler var. }\end{array}$ & 0,685 & & \\
\hline $\begin{array}{l}\text { DKL53: Ziyaret edilen diğer destinasyonlarla karşılaştırıldığında, } \\
\text { adada cazip bir gelenek ve kültür var. }\end{array}$ & 0,599 & & \\
\hline $\begin{array}{l}\text { DKL56: Ziyaret edilen diğer destinasyonlarla karşılaştıııldığında } \\
\text { adada çeşitli alt kültürler bulunmaktadır. }\end{array}$ & 0,550 & & \\
\hline $\begin{array}{l}\begin{array}{l}\text { DKİ48: Ziyaret edilen diğer ülkelerle karşılaştırıldığında, ada } \\
\text { büyüleyicidir. }\end{array} \\
\end{array}$ & 0,501 & & \\
\hline Destinasyon Kişiliği (DKI) & & $\mathbf{1 0 , 4 3 5}$ & 3,660 \\
\hline $\begin{array}{l}\text { DKİ46: Ziyaret edilen diğer destinasyonlarla karşılaştırıldığında ada } \\
\text { dostçadır. }\end{array}$ & 0,771 & & \\
\hline $\begin{array}{l}\text { Dİ35: Ziyaret edilen diğer ülkelerle karşılaştırıldığında adadaki } \\
\text { insanlar daha dostça davranıyor. }\end{array}$ & 0,738 & & \\
\hline $\begin{array}{l}\text { Dí29: Ziyaret edilen diğer destinasyonlarla kıyaslandığında, adada } \\
\text { memnun edici bir hava var. }\end{array}$ & 0,724 & & \\
\hline $\begin{array}{l}\text { Dİ46: Ziyaret edilen diğer destinasyonlarla karşılaştırıldığında, adada } \\
\text { iyi bir kamu güvenliği var. }\end{array}$ & 0,627 & & \\
\hline $\begin{array}{l}\text { DKİ7: Ziyaret edilen diğer destinasyonlarla karşılaştırıldığında ada } \\
\text { güvenilirdir. }\end{array}$ & 0,590 & & \\
\hline Destinasyon İmajı (DI) & & 9,765 & 3,092 \\
\hline $\begin{array}{l}\text { Dí28: Ziyaret edilen diğer destinasyonlarla karşılaştırıldığında adada } \\
\text { meyve çeşitliliği fazla. }\end{array}$ & 0,640 & & \\
\hline $\begin{array}{l}\text { DKA41: Ziyaret edilen diğer destinasyonlarla karşılaştırıldı̆̆ında } \\
\text { adada yüksek kalitede resepsiyon hizmetleri bulunmaktadır. }\end{array}$ & 0,614 & & \\
\hline $\begin{array}{l}\text { Dİ31: Ziyaret edilen diğer destinasyonlarla karşılaştırıldığında, adada } \\
\text { rekreasyon faaliyetleri (örneğin, eğlence parkı, kuş gözlemciliği, golf } \\
\text { sporu, vb.) İçin iyi firsatlar bulunmaktadır. }\end{array}$ & 0,611 & & \\
\hline $\begin{array}{l}\text { Dí27: Ziyaret edilen diğer destinasyonlara göre adada yemek çeşitliliği } \\
\text { bulunmaktadır. }\end{array}$ & 0,608 & & \\
\hline $\begin{array}{l}\text { DKA44: Ziyaret edilen diğer destinasyonlarla karşılaştırıldığında, } \\
\text { adada iyi alışveriş olanakları bulunmaktadır. }\end{array}$ & 0,569 & & \\
\hline $\begin{array}{l}\text { Di்30: Tavsiye edilen diğer destinasyonlarla kıyaslandığında, adada } \\
\text { güzel gece hayatı ve eğlence bulunmaktadır. }\end{array}$ & 0,521 & & \\
\hline Destinasyon Bilgisi (DB) & & 9,011 & 2,092 \\
\hline $\begin{array}{l}\text { DKA45: Ziyaret edilen diğer destinasyonlarla kıyaslandığında, adada } \\
\text { paranın değeri yüksektir. }\end{array}$ & 0,692 & & \\
\hline $\begin{array}{l}\text { DF49: Ziyaret edilen diğer destinasyonlarla karşılaş̧ırıldığında, adayı } \\
\text { daha sik duydum. }\end{array}$ & 0,559 & & \\
\hline $\begin{array}{l}\text { DF50: Ziyaret edilen diğer destinasyonlarla karşılaştırıldığında, adada } \\
\text { temsili semboller bulunmaktadır. }\end{array}$ & 0,511 & & \\
\hline Destinasyon Farkındalığı (DF) & & 8,150 & $\mathbf{1 , 6 6 5}$ \\
\hline $\begin{array}{l}\text { DKA42: Ziyaret edilen diğer destinasyonlarla karşılaştırılldığında, } \\
\text { adada çekici yerel yemekler bulunmaktadır. }\end{array}$ & 0,755 & & \\
\hline $\begin{array}{l}\text { DF52: Ziyaret edilen diğer destinasyonlarla karşılaştırıldığında, adada } \\
\text { tanıtım materyallerinde etkileyici bir logo bulunmaktadır. }\end{array}$ & 0,746 & & \\
\hline $\begin{array}{l}\text { DF51: Ziyaret edilen diğer destinasyonlarla karşılaştırıldığında, adanın } \\
\text { tanıtım materyallerinde etkileyici bir slogan var. }\end{array}$ & 0,593 & & \\
\hline Toplam & & 62,038 & \\
\hline
\end{tabular}

Faktör Çıkarma Yöntemi: Temel Bileşen Analizi.

Döndürme Yöntemi: Kaiser Normalizasyonu ile Varimax. Rotasyon, 13 yinelemede yakınsadı.

Destinasyon marka kimliği ölçeği için yapılan KMO testi sonucu bulunan katsayı $(0,924)$ olduğundan veriler faktör analizi için "mükemmel” düzeyde uygundur. Ayrıca Bartlett Küresellik Testi sonuçları incelendiğinde ki kare $(\chi 2=5440,709 ; \mathrm{df}=171 ; \mathrm{p}=0,000)$ değerinin anlamlı olduğunu göstermektedir. 
P (sig) 0, 000<0,005 olduğundan Bartlett Küresellik Testi sonucu da anlamlıdır. Yani değişkenler arasında yüksek korelasyon mevcuttur ve veriler çoklu normal dağılımdan gelmiş demektir. Elde edilen her iki bulguya göre veriler faktör analizi için uygundur (Karagöz, 2019: 680).

Yapılan AFA sonucunda faktör yüklerinin 0,45 ve üzerinde değerler aldığı görülmektedir. Bu nedenle ölçekteki maddeler analizden çıkarılmamıştır. Ayrıca ölçekte tüm maddeler 6 faktör altında dağılım göstermiştir. 1. Faktör: Destinasyon Kalitesi (DKA), 2. Faktör: Destinasyon Kültürü (DKL), 3. Faktör: Destinasyon Kişiliği (DKI), 4. Faktör: Destinasyon İmajı (DI), 5. Faktör: Destinasyon Bilgisi (DB), 6. Faktör: Destinasyon Farkındalığı (DF) olarak adlandırılmıştır.

Faktörlerin özdeğerleri; destinasyon kalitesi faktörü için 4,561; destinasyon kültürü faktörü için 4,440; destinasyon kişiliği faktörü için 3,660; destinasyon imajı faktörü için 3,092; destinasyon bilgisi faktörü için 2,092; destinasyon farkındalığ1 faktörü için 1,665 olarak tespit edilmiştir. Faktörlerin toplam varyans açıklama oranları; destinasyon kalitesi faktörü için 13,626; destinasyon kültürü faktörü için 11,051; destinasyon kişiliği faktörü için 10,435; destinasyon imajı faktörü için 9,765; destinasyon bilgisi faktörü için 9,011; destinasyon farkındalığı faktörü için 8,150 olarak hesaplanmıştır. Destinasyon marka kimliği ölçeğinin toplam varyans açıklama oranı \%62,038 olarak olduğundan ölçeğin yapı geçerliliği var demektir.

\section{Doğrulayıcı Faktör Analizi}

Doğrulayıcı faktör analizi (DFA) uyum istatistiklerine dayanan gelişmiş bir hipotez testidir. DFA, verinin temelindeki yapıyı değerlendiren açıklayıcı faktör analizinin (AFA) uzantısıdır (Erkorkmaz vd., 2013: 211). Açıklayıcı faktör analizi, bir veri matrisinde yer alan temel yapıyı tanımlamayı ve bu yapıyı oluşturan her bir boyutu ayrı ayrı belirlemeyi amaçlar (Hair vd., 1998: 90). Doğrulayıcı faktör analizi ise önceden belirlenmiş bir ilişkiyi test etmede kullanılan çok değişkenli bir tekniktir (Hair vd., 1998: 579). Özellikle ölçek geliştirme çalışmaları kapsamında toplanan veriler genellikle açıklayıcı ve doğrulayıcı faktör analizlerinin birlikte uygulanmasını gerektirmektedir. Literatürde bazı çalışmalarda geçerlilik ve güvenilirlikleri daha önce saptanmış olan çalışmalarda direkt doğrulayıcı faktör analizlerinin uygulanması tavsiye edilmesine rağmen özellikle sosyal bilimlerde, böyle ölçeklerin kullanılmasında örneklemlerin, zamanın, kültürlerin ve yaşam biçimlerinin farklılık gösterebilmesinden dolayı iki analizin de uygulanması gerekmektedir. Ayrıca faktör analizlerinde genellikle yapısal geçerliliğin ölçülmesi, iki faktör analizinin de birlikte uygulanması gerektiğini dolayısıyla yapının örnekleme uygunluğunun test edilmesini ve doğrulanması gerektiğini göstermektedir (Kayapınar, 2018: 587). 
Çalışmada açıklayıcı faktör analizi yapıldıktan sonra verilerin oluşan yapıya uygunluğunun kontrol edilmesi gerekmektedir. Bunun içinde doğrulayıcı faktör analizi yapılmıştır. Ölçeğin geçerlik ve güvenirliğini test etmek amacıyla AMOS 20 programı ile doğrulayıcı faktör analizi yapılmıştır. Doğrulayıcı faktör analizi ile kuramsal yapıya uygun olarak geliştirilen ölçme aracından elde edilen veriler doğrultusunda, söz konusu yapının doğrulanıp doğrulanmadığı test edilmiştir.

\subsection{Destinasyon Çekiciliği Ölçeği Doğrulayıcı Faktör Analizi}

Yapılan DFA sonucunda 25 maddeli ve 5 faktörlü olarak tanımlanan destinasyon çekiciliği ölçeği maddelerinden faktör yükleri $(\mathrm{FY}<0,50)$ olan 5 madde elenmiştir. BNZ17: "Ada görsel açıdan diğerlerinden farklı görünüyor.”, BNZ19: “Adanın kendine has yerel özellikleri var.”, BNZ20: “Adanın özel temalı alanları var.”, UYG21: “Burası hayat tecrübelerimle bağlantı kurabilir.”, UYG25: "Burayı ziyaret etmek, nasıl olmak istediğimi temsil etmekte.” maddeleri elenmiştir. Analizde yer alan 25 madde ile ölçek açıklayıcı faktör analizinde yer aldığı gibi 3 faktör olarak analiz edilmiştir. Destinasyon çekiciliği ölçeğinde faktör yükleri $(0,530 ; 0,880)$ aralığında yer almaktadır.

\section{Şekil 1. Destinasyon Çekiciliği Ölçeği DFA Faktör Yapısı}

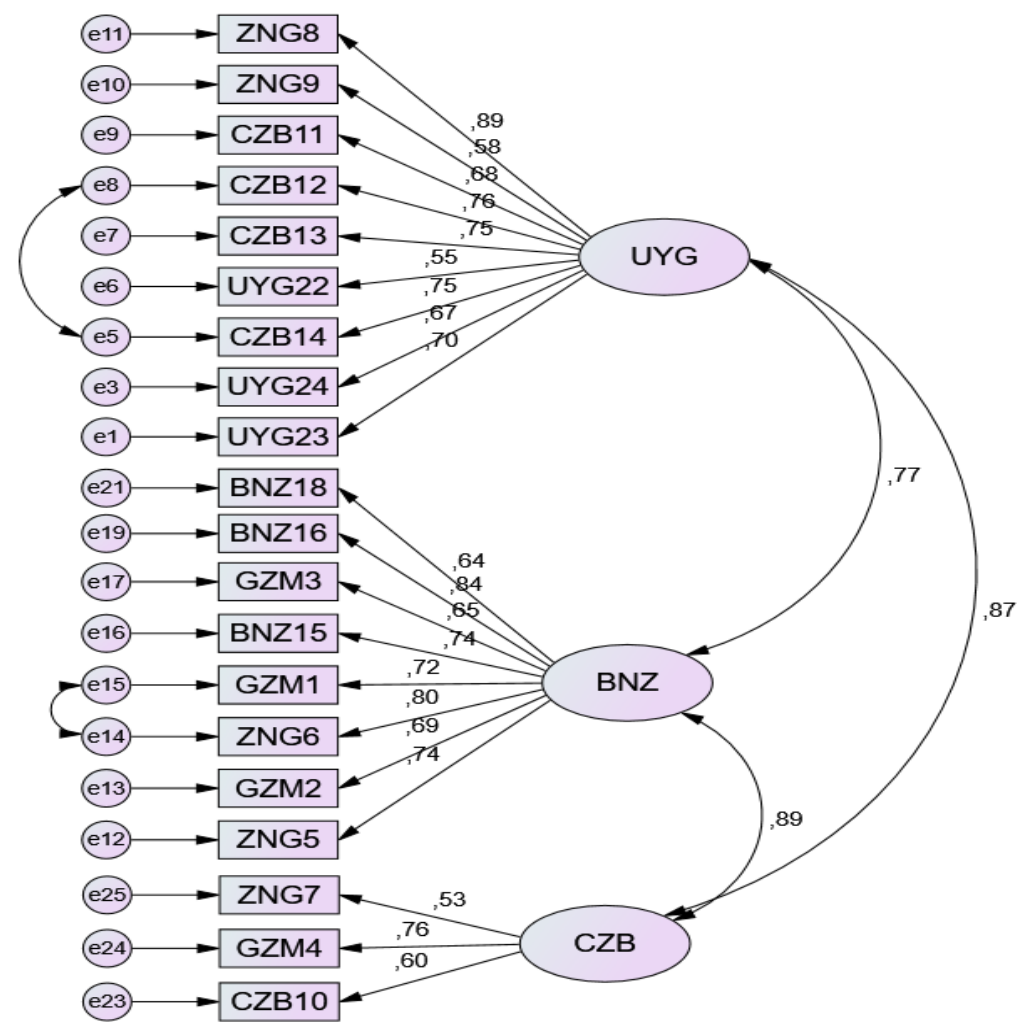


Tablo 4. Destinasyon Çekiciliği Ölçeği DFA Uyum İndeksleri Sonuçları

\begin{tabular}{|l|l|l|l|l|l|l|}
\hline İndeks & $\boldsymbol{X}^{\mathbf{2}}$ & $\boldsymbol{X}^{\mathbf{2}} / \boldsymbol{d f}$ & RMSEA & GFI & CFI & SRMR \\
\hline $\begin{array}{l}\text { Destinasyon } \\
\text { Çekiciliği Ölçeği }\end{array}$ & 279,615 & 1,877 & 0,074 & 0,854 & 0,929 & 0,0609 \\
\hline
\end{tabular}

Öngörülen model ile gözlenen değişkenler arası uyum bazı referans değerler ile kıyaslanarak değerlendirilir. $\mathrm{Bu}$ değerlerden ilki yaklaşık hataların ortalama karekökü (RMSEA)'dür. RMSEA araştırmacıya bilinmeyen fakat optimum şekilde planlamış olduğu parametrelerin, ana kütlenin kovaryans matrisi ile ne derece uyumlu olup olmadı̆̆ı hakkında bilgi veren bir istatistiktir (Byrne, 2011: 664). RMSEA’nın \%95 güven aralığında alabileceği değerler 0,03 ile 0,08 aralığında olabilir, 0,08'in üzerindeki değerler kötü bir model uygunluğuna işaret edecektir (Rigdon, 1996: 369-379). Bu bağlamda kullanılan diğer bir ölçüt ise ki-kare değerinin serbestlik derecesine bölünmesidir. Ki-kare değeri (CMIN ve CMIN/DF) modelin genel uygunluğunu test etmek amaciyla kullanılan en temel ölçümdür. Bu değer örnek kovaryans matrisi ve model tarafından uyarlanmış olan (modellenen) kovaryans matrisi arasında fark olup olmadığını değerlemeye yaramaktadır (Hu ve Bentler, 1999:2). Uygun bir modelin $\mathrm{p}<0.005$ 'de anlamsız sonuçlar vermesi beklenmektedir (Barrett, 2007: 815- 824). Uyum iyiliği indeksleri olarak ifade edilen, karşılaştırmalı uyum endeksi (Comperative Fit Index; CFI), uyum iyiliği endeksi (Goodness of Fit Index; GFI) en az 0,90 olması gerektiği ifade edilirken 0, 95-1,00 arası değerin mükemmel uyuma işaret ettiği ifade edilmektedir (Hu ve Bentler, 1999:5).

Destinasyon Çekiciliği ölçeği DFA analizinde model test değerleri kabul edilebilir uyum sınırları dahilinde yer aldığından destinasyon çekiciliği ölçeğinin, doğrulayıcı faktör analizinin araştırmanın örnekleminde geçerli olduğu anlaşılmaktadır.

\subsection{Destinasyon Marka Kimliği Ölçeği Doğrulayıcı Faktör Analizi}

Literatürde 32 maddeli ve 5 faktör olarak tanımlanan destinasyon marka kimliği ölçeği maddelerinden faktör yükleri $(\mathrm{FY}<0,50)$ olan 5 madde elenmiştir Dİ26: "Ziyaret edilen diğer destinasyonlarla karşılaştırıldığında adada güzel görüntüler (doğal güzellikler, tarihi yapılar, manzaralar) var.” Dİ31: “Ziyaret edilen diğer destinasyonlarla karşılaştırıldığında, adada rekreasyon faaliyetleri (örneğin su sporları (windsurf, kitesurf, dalış), doğa sporları (kuş gözlemciliği, trekking) için iyi firsatlar bulunmaktadır.” Dİ34: “Ziyaret edilen diğer destinasyonlarla karşılaştırıldığında ada güvenli bir yer.” DKA45: "Ziyaret edilen diğer destinasyonlarla karşılaştırıldığında, adada paranın değeri yüksektir." DKL56: "Ziyaret edilen diğer destinasyonlarla karşılaştırıldı̆̆ında adada çeşitli alt kültürler bulunmaktadır." Maddeleri elenen maddelerdir. Analizde yer alan 27 madde ile ölçek 6 faktörlü olarak 
analiz edilmiştir. Destinasyon marka kimliği ölçeğinde faktör yükleri $(0,580 ; 0,920)$ aralığında yer almaktadır.

Şekil 2. Destinasyon Marka Kimliği Ölçeği DFA Faktör Yapısı

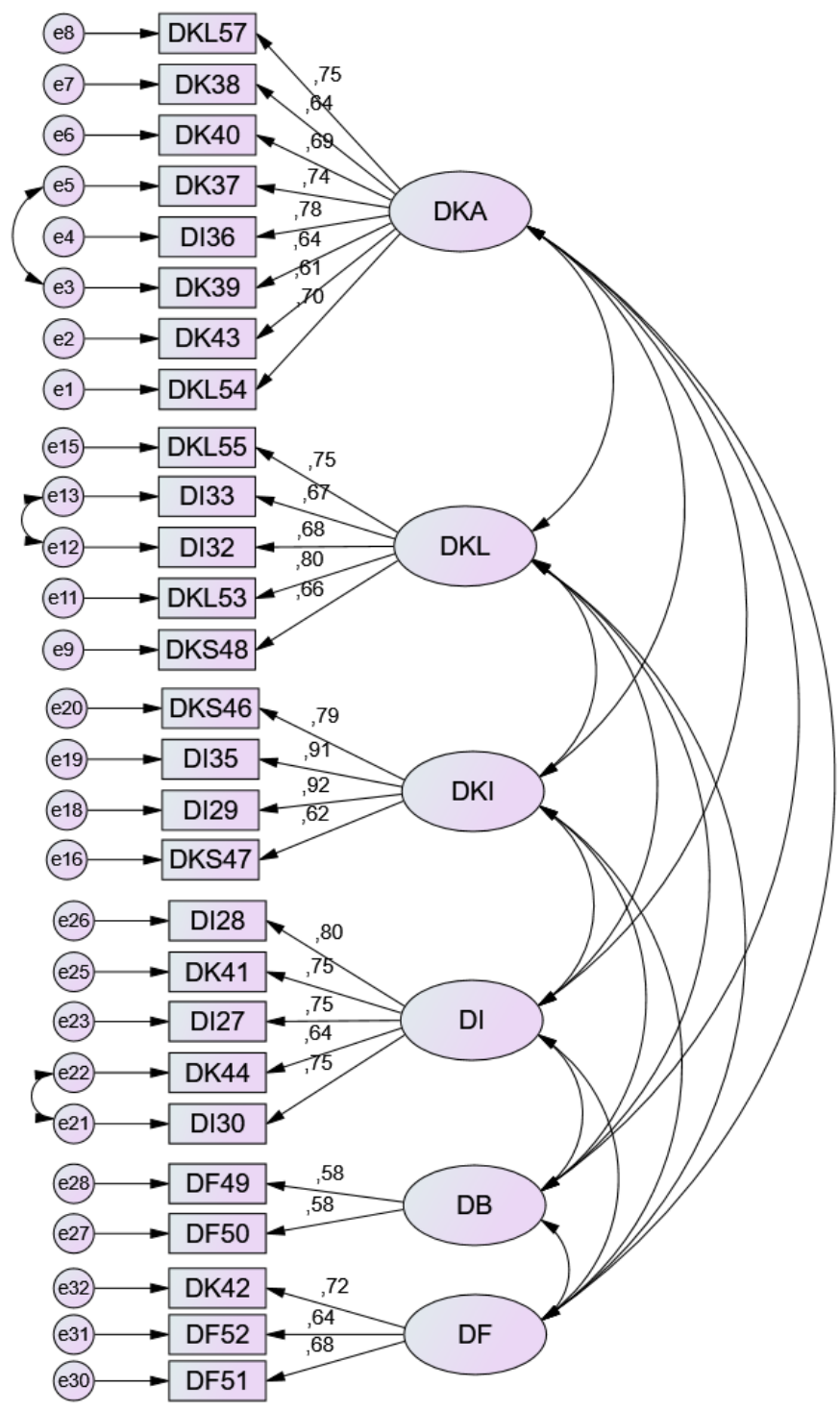

Tablo 5. Destinasyon Marka Kimliği Ölçeği Uyum İndeksleri Sonuçları

\begin{tabular}{|l|l|l|l|l|l|l|}
\hline İndeks & $\boldsymbol{X}^{2}$ & $\boldsymbol{X}^{2} / \boldsymbol{d} \boldsymbol{f}$ & RMSEA & GFI & CFI & SRMR \\
\hline $\begin{array}{l}\text { Destinasyon Marka } \\
\text { Kimliği Ölçeği }\end{array}$ & 547,486 & 1,935 & 0,077 & 0,856 & 0,912 & 0,0588 \\
\hline
\end{tabular}

Destinasyon marka kimliği ölçeği DFA analizinde model test değerleri kabul edilebilir uyum sınırları dahilinde yer aldığından destinasyon marka kimliği ölçeğinin doğrulayıcı faktör analizinin 
araştırmanın örnekleminde geçerli olduğu anlaşılmaktadır. Aşağıdaki tabloda DFA'dan elde edilen katsayıların detayları yer almaktadır.

Tablo 6. Destinasyon Çekiciliği ve Destinasyon Marka Kimliği Ölçeklerinden Hesaplanan Alpha, AVE ve CR Değerleri

\begin{tabular}{|l|l|l|l|l|}
\hline Ölçek & Boyut & CRA & AVE & CR \\
\hline \multirow{3}{*}{$\begin{array}{l}\text { Destinasyon } \\
\text { Cekiciliği }\end{array}$} & UYG (Uygunluk) & 0,911 & 0,506 & 0,900 \\
\cline { 2 - 5 } & BNZ (Benzerlik) & 0,891 & 0,533 & 0,895 \\
\cline { 2 - 5 } & CZB (Cazibe) & 0,782 & 0,452 & 0,708 \\
\hline \multirow{4}{*}{$\begin{array}{l}\text { Mestinasyon } \\
\text { Marka Kimliği }\end{array}$} & DKA (Destinasyon Kalitesi) & 0,894 & 0,484 & 0,881 \\
\cline { 2 - 5 } & DKL (Destinasyon Kültürü) & 0,821 & 0,511 & 0,839 \\
\cline { 2 - 5 } & DKI (Destinasyon Kişiliği) & 0,893 & 0,674 & 0,890 \\
\cline { 2 - 5 } & DI (Destinasyon İmaji) & 0,813 & 0,548 & 0,858 \\
\cline { 2 - 5 } & DB (Destinasyon Bilgisi) & 0,762 & 0,541 & 0,702 \\
\cline { 2 - 5 } & DF (Destinasyon Farkındalığı) & 0,709 & 0,461 & 0,719 \\
\hline
\end{tabular}

CRA: Cronbach's Alpha CR: Birleşik Güvenilirlik AVE: Açıklanan Ortalama Varyans

Cronbach's Alpha $(\alpha)$ değerinin faktör altındaki soruların toplamdaki güvenilirlik seviyesini göstermektedir. Alfa katsayısı, ölçek içinde bulunan maddelerin iç tutarlılığının bir ölçüsüdür. Alfa katsayısına bağlı olarak ölçeğin güvenilirliği 0,80-1,00 arası "yüksek güvenirlik”, 0,60-0,80 arası “oldukça güvenilir”, 0,40-0,60 arası "güvenilirlik düşük”, 0,40'dan aşağısı "güvenilir değil” şeklinde yorumlanmaktadır (Kalaycı, 2006: 405).

Araştırmada yer alan destinasyon çekiciliği $(0,872)$, destinasyon marka kimliği $(0,810)$ her iki ölçekte (CRA $>0,80)$ olduğundan yüksek güvenilirlik seviyesindedir. Destinasyon çekiciliği ölçeğinde hesaplanan alt faktörlerdeki güvenilirlik değerlerinde Cronbach's Alpha (CRA) değerleri uygunluk, benzersizlik ve cazibe faktörlerinde $(\mathrm{CRA}>0,80)$ bulunduğundan yüksek güvenilirlik düzeyindedir. Destinasyon marka kimliği ölçeğinde hesaplanan alt faktörlerdeki güvenilirlik değerlerinde CRA değerleri, destinasyon kalitesi, destinasyon kültürü, destinasyon kişiliği, destinasyon İmaj1 faktörlerinde $(C R A>0,80)$ bulunduğundan yüksek güvenilirlik düzeyindedir. Sadece destinasyon bilgisi ve destinasyon farkındalığı faktörlerinde (CRA>0,60) bulunduğundan "oldukça güvenilir" düzeydedir.

Yapı güvenirlik değerleri (CR) için ise kabul edilebilir değerin 0,70 ya da 0,70 'in üzerinde olması gerekmektedir. Yapı güvenirliğinde 0,60 ile 0,70 arasındaki değerler de kabul edilebilir sınırlar içerisindedir (Hair vd., 2009: 708-710). Birleşik güvenilirlik değeri (CR $\geq 0.70)$ olduğunda birleşik güvenilirlik şartı sağlanmaktadır.

Yakınsama geçerliliğinin göstergesi açıklanan ortalama varyans (AVE) değeridir. Yakınsama geçerliliğinin teyit edilebilmesi için açıklanan ortalama varyansın $(A V E \geq 0,50)$ olması gereklidir. Ancak birleşik güvenilirlik değerlerinin tüm boyutlarda $(\mathrm{CR} \geq 0,70)$ olması durumunda AVE değerlerinin (AVE $\geq 0,40)$ olması yeterli sayılmıştır (Fornell ve Larcker, 1981: 39). Fornell ve Larcker 
'a (1981) göre, AVE değerleri 0,50 'ten küçük, ancak birleşik güvenirlik değerleri 0,60'tan büyükse, yapısal geçerlilik için bileşik güvenirlik değerleri incelenir (Kayapınar ve Lorcu, 2020: 120). Destinasyon marka çekiciliği ölçeğinde uygunluk ve benzersizlik faktörlerinde açıklanan ortalama varyans değerleri (AVE $\geq 0,50)$, cazibe faktörünün açıklanan ortalama varyans değeri ise $(\mathrm{AVE} \geq 0,40)$ bulunmuştur. Birleşik güvenilirlik değerlerinin tüm faktörlerde $(\mathrm{CR} \geq 0,60)$ olması durumunda açıklanan ortalama varyans değerinin $(A V E \geq 0,40)$ olması yeterli sayılmıştır. Destinasyon marka kimliği ölçeğinde açıklanan ortalama varyans değerlerinin ( $A V E \geq 0,50)$ olduğu faktörler, destinasyon kültürü, destinasyon kişiliği, destinasyon imajı, destinasyon bilgisi faktörleridir. Destinasyon kalitesi ve destinasyon farkındalığ faktörlerinde ise $(A V E \geq 0,40)$ bulunmuştur. Birleşik güvenilirlik değerlerinin tüm boyutlarda $(\mathrm{CR} \geq 0,60)$ olması durumunda açıklanan ortalama varyans değerlerinin $(A V E \geq 0,40)$ olması yeterli sayılmıştır. Bu nedenle her iki ölçek için de yakınsama geçerliliğinin sağlanmış olduğu anlaşılmaktadır.

\section{SONUÇ}

Liu vd. (2017)'nin destinasyon çekiciliği ve Tsaur vd. (2016)'nın destinasyon marka kimliği ölçeklerinin Türkçeye uyarlanması amacıyla gerçekleştirilen bu araştırmanın, sadece metodolojik bir çalışma değil, aynı zamanda adalarda turizm, destinasyon çekiciliği, destinasyon marka kimliği gibi kavramları açıklayarak literatüre kazandırılması açısından önemi bulunmaktadır.

Bu çalışma, Gökçeada’ya tatil amaçlı gelen turistler üzerinde yürütülmüştür. Araştırmada yer alan turistlerin demografik özellikleri incelenmiştir. Araştırmanın amacı doğrultusunda ölçeklerde yer alan ifadelerin hem faktör hem de madde bazında geçerlik ve güvenirlikleri ortaya koyulmuştur. Destinasyon çekiciliği ölçeğinden 5 madde, destinasyon marka kimliği ölçeğinden 5 madde elenmiş ve oluşan yeni faktör yapılarıyla içeriklerin geçerlik ve güvenirlik açısından uygulanabilir olduğu sonucuna ulaşılmıştır. Destinasyon çekiciliğini ölçeğinin toplam güvenirlik değeri $(\alpha) 0,872$; destinasyon marka kimliği ölçeğinin güvenirlik değeri $(\alpha)$ 0,810 olarak bulunmuştur. Her iki ölçekte yüksek güvenilirlik seviyesindedir. Bu durum ölçeklerin farklı katılımcı kitlelere uygulanması sonucunda farklı sonuçlara ulaşabileceğini göstermektedir. Elde edilen bulgular sonucunda iki ölçeğinde uyum indekslerinin kabul edilebilir düzeyde olduğu ve tüm faktörlerin birbiriyle olumlu ve anlamlı düzeyde ilişkili olduğu belirlenmiştir. Bu ölçeklerin Türkçe uyarlamalarının ülkemizde destinasyon markalaması konusunda yapılacak araştırmalara katkıda bulunması beklenmektedir.

Doğal güzellikleri bakımından zengin, sakin, huzur veren zengin manzaraların olduğu ada destinasyonlarına olan ilgi her geçen gün artmaktadır. Adalar, içinde barındırdıkları çeşitli çekicilik unsurları ve kendilerine has kimlikleri ile turistler tarafından daha sık ziyaret edilen destinasyonlar haline gelmeye başlamışlardır. Bu nedenle gelecek araştırmalarda ada destinasyonları üzerinde daha 
farklı araştırmalar yapılarak bu destinasyonlarda turizmin canlandırılmasına yönelik katkılarda bulunulması önerilmektedir. Ayrıca farklı destinasyonlarda, destinasyon çekiciliği ve destinasyon marka kimliği ile ilgili çalışmalar yapılarak, daha fazla turiste ulaşılması ve bu destinasyonlar arasındaki farklılıkların ortaya çıkarılması önerilmektedir. Bu konuya ilişkin gelecek araştırmalarda, farklı destinasyon çekiciliği ve destinasyon marka kimliği ölçeklerinin Türkçeye uyarlanması faydalı olacaktır. 


\section{KAYNAKÇA}

Aaker, D. (1995). Strategic Market Management, New York: John Wiley\&Sons, Inc.

Aaker, J. L. (1997). Dimensions of Brand Personality. Journal of Marketing Research, 34 (3), 347-356.

Aksu, M. (2015). Bozcaada Destinasyonu. 1. Baskı, Ankara: Detay Yayıncılık.

Aktaş, S. ve Batman, S. (2010). Efsanelerin Turistik Çekicilik Üzerine Etkileri: Profesyonel Turist Rehberlerine Yönelik Bir Araştırma. e-Journal of New World Sciences Academy, 5 (4), 367-395.

Alpar, R. (2013). Uygulamalı Çok Değişkenli İstatistiksel Yöntemler. Ankara: Detay Yayınc1lik.

Ayazlar, R. ve Ayazlar, G. (2016). Yerel Halkın Turizmin Etkilerine Yönelik Tutumunda Aidiyet Duygusu ve Yaşam Tatmininin Rolü. Atatürk Üniversitesi Sosyal Bilimler Enstitüsü Dergisi, 20 (4), 1451-1470.

Barrett, P. (2007). Structural Equation Modelling: Adjudging Model Fit. Personality and Individual Differences, 42 (5), 815-824.

Basım, N. ve Beğenirbaş, M. (2012). Çalışma Yaşamında Duygusal Emek: Bir Ölçek Uyarlama Çalışması, Yönetim ve Ekonomi, 19 (1), 77-90.

Büyüköztürk, Ş. (2016). Sosyal Bilimler İçin Veri Analizi El Kitabı, İstatistik, Araştırma Deseni SPSS Uygulamaları ve Yorum, Pegem Akademi.

Byrne, B. M. (2011). Structural Equation Modeling with AMOS Basic Concepts, Applications, and Programming (Multivariate Applications Series), Routledge, New York.

Çetinsöz, B. C. ve Karakeçili, G. (2018). Turistik Destinasyonlarda Tüketici Temelli Marka Değerinin Ölçülmesi: Anamur Üzerine Bir Araştırma. Gaziantep University Journal of Social Sciences, 17 (1), 126-138.

Çiçek, E. ve Pala, U. (2017). Destinasyon Markalaşması Üzerine Bir Araştırma: Tarsus Örneği. Çağ Üniversitesi Sosyal Bilimler Dergisi, 14 (2), 25-47.

Çokluk, Ö., Şekercioğlu, G. ve Büyüköztürk, Ş. (2016). Sosyal Bilimler İçin Çok Değişkenli İstatistik: SPSS ve Lisrel Uygulamaları. Ankara: Pegem Akademi.

Dahiya, K., S., Batra, K., D. ve Kumar, V. (2020). Antecedents and Consequences of Destination Brand Experience (DBE): A Conceptual Framework. International Journal of Hospitality \& Tourism Systems, 13 (1), 61-67.

Davras, Ö. ve Uslu, A. (2019). Destinasyon Seçimini Belirleyen Faktörlerin Destinasyon Memnuniyeti Üzerindeki Etkisi: Fethiye'de İngiliz Turistler Üzerinde Bir Araştırma. Manas Sosyal Araştırmalar Dergisi, 8 (1), 679-696. 
De Charnatony, L. (1999). Brand Management Through Narrowing The Gap Between Brand Identity and Brand Reputation. Journal of Marketing, 15 (1/3), 157-179.

Demir, Ş. (2010). Çekici Faktörlerin Destinasyon Seçimine Etkisi: Dalyan Örneği. Ege Akademik Bakış, 10 (3), 1041-1054.

Dülgeroğlu, O. ve Atay, L. (2019). Troya Ören Yeri’nin Destinasyon Kişiliği. Gastroia: Journal of Gastronomy and Travel Research, 3 (1), 147-161.

Echtner, C. M., ve Ritchie, J. R. B. (1993). The Measurement of Destination Image: An Empirical Assessment. Journal of Travel Research, 31(4), 3-13.

Emekli, G. (2005). Avrupa Birliği'nde Turizm Politikaları ve Türkiye'de Kültürel Turizm. Ege Coğrafya Dergisi, 14 (2005), 99-107.

Erdemir, E. (2018). Yönetim Araştırmalarında Ölçek Kullanımı. Yönetim ve Organizasyon Araştırmaları Dergisi. 3 (2), 5-32.

Eren, D., Y1lmaz, İ. ve Atasoy, F. (2017). Turizmde Destinasyon Seçimini Etkileyen Çekici Faktörler: Yozgat Üzerinde Bir Değerlendirme. II. Uluslararası Bozok Sempozyumu. 480-490.

Erkorkmaz, Ü., Etikan, İ., Demir, O., Özdamar, K. ve Sanisoğlu, Y., S. (2013). Doğrulayıcı Faktör Analizi ve Uyum Endeksleri. Türkiye Klinikleri J Med Sci, 33 (1), 210-223.

Florek, M., Insch, A. ve Gnoth, J. (2006). City Council Websites As A Means of Place Brand Identity Communication. Place Branding, 2 (4), 276-296.

Fornell, C. ve Larcker, F.D. (1981). Evaluating Structural Equation Models with Unobservable Variables and Measurement Error. Journal of Marketing Research, 18 (1), 39-50.

Freire, J., R. ve Gertner, R., K. (2021). The Relevance of Food for The Development of a Destination Brand. Place Branding and Public Diplomacy, 17, 193-204.

Gönenç, Güler, E. (2010). Destinasyon Pazarlamasında Edirne Markalama Süreci. 1. Baskı, Ankara: Detay Yayıncılık.

Gül, M., Gül, K. ve Saçkes, E. (2019). Termal Turizmde Ziyaretçilerin Destinasyon İmajı Algısı: Sındırgı Örneği. Uluslararası Sosyal ve Ekonomik Bilimler Dergisi, 9 (2), 57-63.

Gülmez, M. ve Dörtyol, İ.T. (2013). Açıklamalı Pazarlama Sözlüğü. 2. Baskı, Detay Yayincilık.

Güneş, E. (2018). Destinasyon Kalite Unsurlarının Analizi: Antalya Örneği. Seyahat ve Otel İşletmeciliği Dergisi, 15 (2), 423-442. 
Hair, J. F., Black, W., Babin, B., Anderson, R. (2009). Multivariated at Aanalysis. N.J: Prentice Hall.

Hair, J.F. Jr., Andreson, R.E. Tahtam, R.L ve Black, W.C. (1998). Multivariate Data Analysis (5th Ed.). New Jersey: Prentice-Hall International Inc.

Hasyim, M., Arafah, B. ve Kuswarini, P. (2020). The New Toraja Destination: Adding Value 'Toraja Coffee' of The Sustainable Tourism Development. IOP Conference Series: Earth and Environmental Science, 575, 1-10.

Herlina, A. (2020). City Branding and Destination Branding in Urban Cultureview. Journal of Advanced Management and Business, 1 (1), 26-29.

Hu, L. ve Bentler, P., M. (1999). Cutoff Criteria for Fit Indexes in Coveriance Structure Analysis: Conventional Criteria Versus New Alternatives. Structural Equation Modelling A Multidisciplinary Journal, 6 (1),1-55.

İnce, M. ve Uygurtürk, H. (2019). Marka Kimliği, Marka Kişiliği, Marka İmajı ve Marka Konumlandırma Alanında Yapılan Lisansüstü Tezlere Yönelik Bir İnceleme. Karabük Üniversitesi Sosyal Bilimler Enstitüsü Dergisi, 9 (1), 224-24.

Kalaycı, Ş. (2006). SPSS Uygulamalı Çok Değişkenli İstatistik Teknikleri. Asil Yayın Dağıtım.

Kaplan, S. (1995). The Restorative Benefits of Nature: Toward An Integrative Framewor. Journal of Environmental Psychology, 15(3), 169-182.

Karadamar, A., A., Öztürk, O. ve Taşkın, Ç. (2018). Turizmde Destinasyon Hayranlığı Modelinin Uygulanması: Uludağ Destinasyon Örneği. Uludağ Üniversitesi İktisadi ve İdari Bilimler Fakültesi Dergisi, 37 (1), 1-27.

Karagöz, Y. (2019). SPSS AMOS META Uygulamalı Nitel-Nicel Karma Bilimsel Araştırma Yöntemleri ve Yayın Etiği, 2. Basım, Ankara: Nobel Yayıncılık.

Kayapınar, Ö. (2018). Pazarlamada Güncel Gelişmeler, 21. Bölüm: Pazarlama Araştırmalarında Güncel Gelişmeler, 571-607, 1. Basım, Ankara: Nobel Akademik Yayınc1lik.

Kayapınar, Ö. ve Lorcu, F. (2020). Handbook of Research on Sustainable Supply Chain Management for the Global Economy, Chapter 6: The Role of Technology Level and Logistics Performance on the Relationship Between Logistics Service Quality and Firm Performance, 107-135, 1. Basım, IGI Global.

Klage, J. P. (1991). Corporate Identity im Kreditwesen. Deutscher Universit ä t Verlag, Wiesbaden.

Koubaa, Y. (2008). Country of Origin, Brand Image Perception and Brand Image Structure. Asia Pacific Journal of Marketing and Logistics, 20 (2), 139-155. 
Kozak, A., M. ve Güçlü, N. (2008). Turizm İşletmelerinde Duygusal Çaba Faktörlerinin İşe Alma Sürecinde Kullanılması Üzerine Bir Araştırma. Anadolu Üniversitesi Sosyal Bilimler Dergisi, 8 (2), 39-56.

Kumar, S., Dhir, A. (2020). Associations Between Travel and Tourism Competitiveness and Culture. Journal of Destination Marketing \& Management, 18, 1-11.

Lee, S., W. ve Xue, K. (2020). A Model of Destination Loyalty: İntegrating Destination Image and Sustainable Tourism. Asia Pacific Journal of Tourism Research, 25 (4), 393-408.

Liu, C.R, Wang, Y.C, Haung, W.Ş. ve C, S.P. (2017). Destination Fascination: Conceptualization and Scale Development. Tourism Management, 63, 255-267.

Moon, H. ve Han, H. (2018). Destination Attributes İnfluencing Chinese Travelers Perceptions of Quality and İntentions for İsland Tourism: A case of Jeju Island. Tourism Management Perspectives, 28, 71-82.

Öcel, Y. (2020). Sosyal Medya Kullanımı ile Marka Farkındalığı ve Marka Sadakati Arasındaki İlişkinin İrdelenmesi. Turkish Studies- Social, 15(2), 257-279.

Özdemir, O. (2019). Destinasyon İmajının Turistlerin Memnuniyetine ve Tekrar Ziyaret Etme Niyetine Etkisi: Mardin İli Üzerine Bir Araştırma. İktisadi ve İdari Yaklaşımlar Dergisi, 1 (1), 65-77.

Pike, S., Bianchi, C., Kerr, G. and Patti, C. (2010). Consumer-Based Brand Equity for Australia As A Long-Haul Tourism Destination in An Emerging Market. International Marketing Review, 27 (4), 434-449.

Putra, R., P. and Razi, A., A. (2019). Value Proposition of Instagrammable Digital Tourism in Forming Brand Identity", Advances in Social Science, Education and Humanities Research, 2nd Social and Humaniora Research Symposium (SoRes), 409, 163-166.

Rigdon, E. E. (1996). CFI Versus RMSEA: A Comparison of Two Fit Indexes for Structural Equation Modeling. Structural Equation Modeling: A Multidisciplinary Journal, 3(4), 369-379.

Rio-Rama, M., Maldonado-Erazo, C., P., Álvarez-Garcia, J. and Duran-Sanchez, A. (2020). Cultural and Natural Resources in Tourism Island: Bibliometric Mapping. Sustainability, 12 (724), 1-26.

Sayar, H., G., Ünübol, H., Ünal, T., H. ve Tarha, N. (2020). Salgın Hastalık Kaygı Ölçeği: Geçerlilik ve Güvenirlik Çalışması, Psikiyatride Güncel Yaklaşımlar, 12 (1), 1-15.

Sezer, İ. (2019). Mitolojik ve Efsanevi Unsurların Turistik Çekicilik Üzerine Etkilerinin Değerlendirilmesi: Giresun Adası Örneği. Turkish Studies Social Sciences, 14 (5), 2463-2500. 
Sirgy, M. J. ve Su, C. (2000). Destination İmage, Self-Congruity, and Travel Behavior: Toward An İntegrative Model. Journal of Travel Research, 38(4), 340-352.

Song, H., Chen, M., J. ve Chen, Y. (2020). Mediating and Moderating Effects in Golf Tourism: Evidence from Hainan Island. Tourism Economics, 1(17), 510-526.

Söylemez, S. ve Duygum, A. (2020). Sosyal Medya Kullanıcıları Açısından Satın Alma Sonrası Marka Farkındalığı ve Tüketici Davranışları Arasındaki İlişki. Journal of Business in The Digital Age, 3(1), 50-62.

Stylidis, D., Terzidou, M. ve Terzidis, K. (2007). Island Tourism and its Socio-Ekonomic Impacts, MIBES, 954-967.

Şahin, H.İ. (2009). Dalyan ve Köyceğiz Çevresinde Gelenek, Turizm ve Folklorizm. Milli Folklor Dergisi, 21(82), 50-58.

Şengül, S. ve Türkay, O. (2016). Yöresel Mutfak Unsurlarının Turizm Destinasyonu Seçimindeki Rolü (Mudurnu Örneği). Uluslararası Yönetim İktisat ve İşletme Dergisi, 12 (29), 63-87.

Şengül, S. ve Türkay, O. (2018). Yöresel Mutfak Marka Değeri Algısının Destinasyon Farkındalı̆̆ 1 ve Destinasyon Sadakati Üzerindeki Etkisi. Atatürk Üniversitesi Sosyal Bilimler Enstitüsü Dergisi, 22 (1), 223-235.

Tabachnick, B. G. ve Fidell, L. S. (2013). Using Multivariate Statistics (6 ed.). Boston: Pearson.

Tavşancıl, E. (2002). Tutumların Ölçülmesi ve SPSS ile Veri Analizi. Nobel Yayıncılık.

Torlak, Ö., Doğan, V. ve Özkara, B., Y. (2014). Marka Farkındalığı, Marka İmaj1, Markadan Etkilenme ve Markaya Güvenin Marka Bağlılığı Üzerindeki Görece Etkilerinin İncelenmesi: Turkcell Örneği. Bilgi Ekonomisi ve Yönetimi Dergisi, 9 (1), 147-161.

Tsaur, S., H., Yen, C., H. ve Yan, Y., T. (2016). Destination Brand Identity: Scale Development and Validation. Asia Pasific Journal of Tourism Research, 21 (12), $1310-1323$.

Ülkü, A. ve Bişkin, F. (2020). Destinasyon Kişiliği ve Benlik Uyumunun Turistlerin Davranışsal Niyetleri Üzerine Etkisi. Selçuk Üniversitesi Sosyal Bilimler Enstitüsü Dergisi, (43), 127-142.

Ünal, A. (2020). Sosyal Medyanın Destinasyon Marka Farkındalığı ve Kalitesi Üzerindeki Etkilerini Belirlemeye Yönelik Bir Araştırma. Journal of Hospitality and Tourism Issues, 2 (1), 13-24.

V.G., G., Park, E. ve Lee, C-K. (2020). Testing the Influence of Destination Source Credibility, Destination Image, and Destination Fascination on the DecisionMaking Process: Case of the Cayman Islands. International Journal of TourismResearch, 1-12. 
Vengesayi, S., Mavonda, F. ve Reisinger, Y. (2009). Tourism Destination Attractiveness: Attractions, Facilities, and People As Predictors. Tourism Analysis, 14 (5), 621636.

Yang, J., Ge, Y., Ge, Q., Xi, J., ve Li, X. (2016). Determinants of Island Tourism Development: The Example of Dachangshan Island. Tourism Management, 55, 261-271.

Zhang, C., Bai, K. (2011). Rural Tourism Destination Brand Personality and Tourist Loyalty- Place Dependence As Intermediary Variable. Journal Tourism Tribune, $26(2), 49-57$. 